\title{
Transition from paediatric to adult services in haemophilia
}

\section{Steve Chaplin}

The need to prepare children and young people with haemophilia for long-term care in the adult sector has long been accepted and is reflected in many national health care policies. Ideally, transition should be an individualised age- and development-appropriate process, through which each young person is empowered to self-manage, with support from their families and multidisciplinary team (MDT). It is widely recognised that young people who are not engaged in self-management frequently become nonadherent to therapy. For those with haemophilia, this can have a life-long impact on joint health and quality of life. In practice, anecdotal reports from individuals suggest that the transition process is often poorly planned, leaving them feeling lost and unsupported by the healthcare professionals who, until this point, have been core members of their support network. Rarely are the views of young people or their families sought regarding the outcome of their transition process. For those with less severe disease or rarer bleeding disorders, and for girls at the menarche, transition is often not addressed at all. This literature review forms the first part of a project that seeks to identify the outcome measures that can be used to drive a nurse-led initiative improvement in transition for young people with bleeding disorders, through changes in both working practices among health professionals and in the underpinning system, which enables them to put such changes into practice.

Keywords: transition, haemophilia, self-management, literature review

Inherited bleeding disorders are lifelong conditions affecting whole families across the generations, whether directly as patients and as carers, or indirectly as family members. Until recently, haemophilia (the most severe of the bleeding disorders) was a disease of childhood. Most affected individuals died prematurely with degenerative joint disease, and haemophilia centres were principally paediatric in nature. Today, with good access to replacement therapies, those born with haemophilia have near-normal life expectancy [1]. Haemophilia centres are either paediatric only, adult only or combined centres treating both children and adults. Transition is therefore a relatively new concept in haemophilia care. There are two main models: transfer within a centre or transfer from one haemophilia care

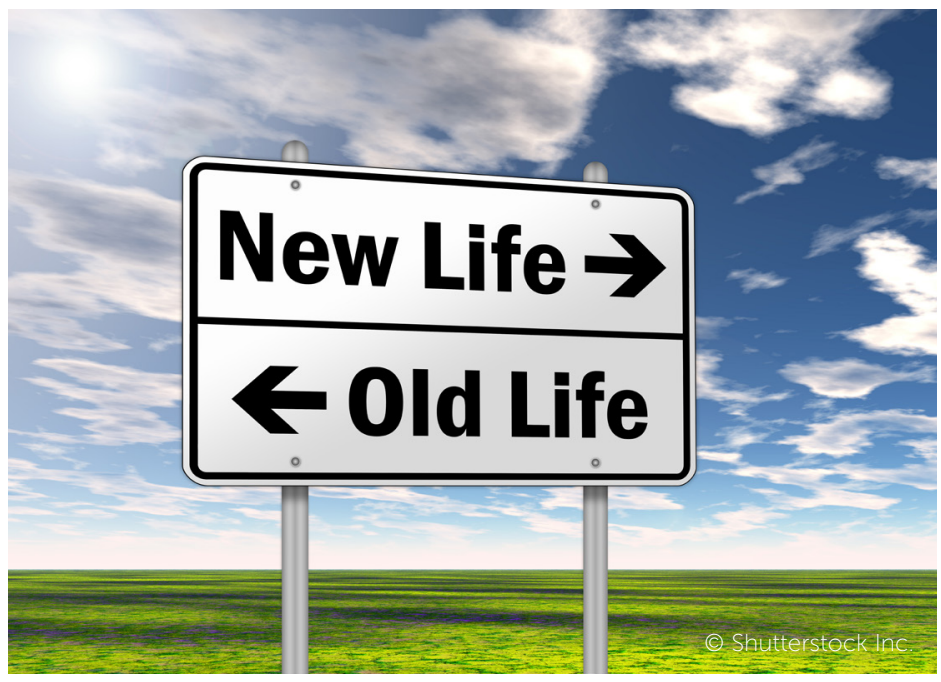

provider to another.

To date, there is very little published literature on effective transition in haemophilia care. Published sources generally reflect medical opinion rather than nurse-led, evidencebased practice. There are currently no regional or national outcome measures for transition for young people with inherited bleeding disorders in the UK.

Transition is routinely discussed for those with severe bleeding phenotypes (predominantly boys with haemophilia). However, anecdotal reports from individuals suggest that the transition process is often poorly planned, leaving them feeling lost and unsupported by the healthcare professionals who, until this point, have been core members of their support network. Rarely are the views of young people or their families sought regarding the outcome of their transition process. For those with less severe disease or rarer bleeding disorders, and for girls at the menarche, transition is often not addressed at all.

Transition needs to be an individualised age- and development-appropriate process, through which each young person is empowered to self-manage, with support from their families and multidisciplinary team (MDT). It is widely recognised that young people who are not engaged in self-management frequently become non-adherent to therapy. For those with haemophilia, this can have a lifelong impact on joint health and quality of life.

Within the haemophilia MDT, specialist nurses could take the lead in facilitating the process of transition. However, 
this requires that nurses have the authority to make referrals; too often the transfer between services is medically led.

This literature review forms the first part of a project aimed at developing a nurse-led initiative to improve transition for young people with bleeding disorders. It was commissioned by Haemnet and supported by the Burdett Trust for Nursing. The project seeks to identify the outcome measures that can be used to drive improvement in transition for young people, through changes in both working practices among health professionals and in the underpinning system, which enables them to put such changes into practice.

\section{Methods}

The main literature search was limited to haemophilia and selected specialties, representing a cross section of experience of organisational development in the UK: congenital heart disease, cystic fibrosis, diabetes, epilepsy and mental disorders. This was subsequently widened to include other specialties for the sections on nurse leadership and patient self-management, due to the lack of publications in the selected topics.
The literature search was conducted in January 2015 and limited to English language publications in PubMed in order to maximise available resources. A flexible time limit was set, based on the availability of systematic reviews (which, having appraised data published prior to their date of publication, obviated the need to include earlier publications). The search strategies are listed in the panel below. Citation abstracts were manually selected for relevance to the UK, service design, outcomes and systematic reviews. Government, NHS and health profession policy papers were identified from the websites of the Department of Health, the Department for Children, Schools and Families, the Royal College of Nursing, the Royal College of Psychiatry, the Royal College of General Practitioners, NHS England, NHS Diabetes, the Care Quality Commission, the National Institute for Health and Care Excellence, the NHS Institute for Innovation and Improvement and the Cochrane Database of Systematic Reviews. Further relevant publications were identified via the references cited in these documents (e.g. publications from agencies such as The King's Fund and the Cystic Fibrosis Trust).

\section{Panel: Strategies for literature search}

\begin{tabular}{|c|c|}
\hline Haemophilia & $\begin{array}{l}\text { ("transition to adult care"[MeSH Terms] OR ("transition"[All Fields] AND "adult"[All Fields] AND "care"[All Fields]) } \\
\text { OR "transition to adult care"[All Fields]) AND (("haemophilia"[All Fields] OR "hemophilia a"[MeSH Terms] OR } \\
\text { "hemophilia a"[All Fields] OR "hemophilia"[All Fields]) OR ("haemophilia"[All Fields] OR "hemophilia a"[MeSH } \\
\text { Terms] OR "hemophilia a"[All Fields] OR "hemophilia"[All Fields])) } \\
\text { Adolescent Health Services AND Continuity of Patient Care/organization \& administration AND (hemophilia } \\
\text { OR haemophilia) }\end{array}$ \\
\hline Congenital heart disease & $\begin{array}{l}\text { ("transition to adult care"[MeSH Terms] OR ("transition"[All Fields] AND "adult"[All Fields] AND "care"[All Fields]) } \\
\text { OR "transition to adult care"[All Fields]) AND ("heart defects, congenital"[MeSH Terms] OR ("heart"[All Fields] } \\
\text { AND "defects"[All Fields] AND "congenital"[All Fields]) OR "congenital heart defects"[All Fields] OR ("heart"[All } \\
\text { Fields] AND "defects"[All Fields] AND "congenital"[All Fields]) OR "heart defects, congenital"[All Fields]) AND } \\
\text { English[lang] } \\
\text { Adolescent Health Services AND Continuity of Patient Care/organization \& administration AND heart defects, } \\
\text { congenital }\end{array}$ \\
\hline Cystic fibrosis & $\begin{array}{l}\text { ("transition to adult care"[MeSH Terms] OR ("transition"[All Fields] AND "adult"[All Fields] AND "care"[All } \\
\text { Fields]) OR "transition to adult care"[All Fields]) AND ("cystic fibrosis"[MeSH Terms] OR ("cystic"[All Fields] AND } \\
\text { "fibrosis"[All Fields]) OR "cystic fibrosis"[All Fields]) AND English[lang] } \\
\text { Adolescent Health Services AND Continuity of Patient Care/organization \& administration AND cystic fibrosis }\end{array}$ \\
\hline Diabetes & $\begin{array}{l}\text { ("transition to adult care"[MeSH Terms] OR ("transition"[All Fields] AND "adult"[All Fields] AND "care"[All Fields]) } \\
\text { OR "transition to adult care"[All Fields]) AND ("diabetes mellitus"[MeSH Terms] OR ("diabetes"[All Fields] AND } \\
\text { "mellitus"[All Fields]) OR "diabetes mellitus"[All Fields] OR "diabetes"[All Fields] OR "diabetes insipidus"[MeSH } \\
\text { Terms] OR ("diabetes"[All Fields] AND "insipidus"[All Fields]) OR "diabetes insipidus"[All Fields]) AND En- } \\
\text { glish[lang] } \\
\text { Adolescent Health Services AND Continuity of Patient Care/organization \& administration AND diabetes }\end{array}$ \\
\hline Epilepsy & $\begin{array}{l}\text { ("transition to adult care"[MeSH Terms] OR ("transition"[All Fields] AND "adult"[All Fields] AND "care"[All } \\
\text { Fields]) OR "transition to adult care"[All Fields]) AND ("epilepsy"[MeSH Terms] OR "epilepsy"[All Fields]) AND } \\
\text { English[lang] } \\
\text { Adolescent Health Services AND Continuity of Patient Care/organization \& administration AND epilepsy }\end{array}$ \\
\hline Mental disorders & $\begin{array}{l}\text { ("transition to adult care"[MeSH Terms] OR ("transition"[All Fields] AND "adult"[All Fields] AND "care"[All Fields]) } \\
\text { OR "transition to adult care"[All Fields]) AND ("mental disorders"[MeSH Terms] OR ("mental"[All Fields] AND } \\
\text { "disorders"[All Fields]) OR "mental disorders"[All Fields]) NOT ("review"[Publication Type] OR "review literature } \\
\text { as topic"[MeSH Terms] OR "review"[All Fields]) AND (hasabstract[text] AND English[lang]) } \\
\text { Adolescent Health Services AND Continuity of Patient Care/organization \& administration AND Mental Health } \\
\text { Services }\end{array}$ \\
\hline Nurse leadership & $\begin{array}{l}\text { ("nurse's role" AND "transition to adult care" [latter term introduced 2012, no earlier term listed] } \\
\text { "nurse" AND "transition" }\end{array}$ \\
\hline Patient self-management & $\begin{array}{l}\text { ("concordance" OR "compliance") AND "transition to adult care" " } \\
\text { "self management" AND ("concordance" OR "compliance") AND "transition" }\end{array}$ \\
\hline
\end{tabular}


A secondary PubMed search was conducted in July and August 2015, specifically focused on relevant publications concerning nurse leadership and patient self-management.

The selected publications were then reviewed to identify evidence to address the following questions:

\section{General}

- What is transition and at what age should it occur?

- What is considered as successful transition from child and adolescent services to adult services, and by whom is this defined?

- Is there any evidence that transition affects health outcomes? If so, what are the characteristics of that transition programme?

- Is transition different for those who develop an illness (e.g. cancer) than for those who are living well with an inherited (or manageable) condition?

\section{Nurse leadership in transition}

- Is there evidence that nurse leadership facilitates successful transition and improves outcomes?

- Are there examples of the different behaviours required for nurse leadership versus nurses' management of the transition process? If yes, what are they?

- What are the changes in working practices, at an individual and organisational level, that will support nurse-led leadership in transition?

\section{Patient self-management}

- Is there evidence that patients take responsibility for selfmanaging their condition?

- If yes, is there evidence that this has a positive impact on transitioning from child to adult services and a positive impact on concordance with an agreed management plan?

- What are the changes in working practices, at an individual and organisational level, that will support successful selfmanagement by patients?

\section{Transition}

Transition is:

"The purposeful, planned process that addresses the medical, psychosocial and educational/vocational needs of adolescents and young adults with chronic physical and medical conditions as they move from child-centred to adult-oriented healthcare systems.." [1]

It has long been recognised as a critically important step in the provision of care to children and young people, and one potentially associated with disruption and discontinuity of care and loss of contact with health and social services [2]. Its importance was acknowledged in the 2004 National Service Framework for Children, Young People and Maternity Services, which stated:
"Young people with additional, and sometimes complex, needs such as mental health problems or disabilities may find it more difficult to make these transitions successfully and they and their families may require additional support. However, these young people often have experiences of poor support during their transition to adulthood. They need high quality, multi-agency support allowing them to have choice and control over life decisions and, in particular, to maximise education, training and employment and leisure opportunities with a view to living independently. High quality transition services should be delivered in a multi-agency context."[3]

But ten years later, the Care Quality Commission (CQC) revealed how poorly different care services work together during transition from children's to adult health services [4]. Following interviews with young people aged $14-25$ who were receiving a children's continuing care package, had life-limiting or life-threatening conditions, or received care from at least three health profession disciplines as a result of long-term or chronic conditions, it concluded that:

"The transition process is variable and that previous good practice guidance had not always been implemented. Young people and families are often confused and at times distressed by the lack of information, support and services available to meet their complex health needs."

This finding in NHS practice reflects published evidence [5-9] suggesting that the NHS has struggled for some time to deliver a patient-centred service for children and young people. NICE is now developing a guideline with the aim of improving practice and outcomes in health and social care [10].

\section{What is transition?}

As the definition implies, transition describes the process by which service users move from services designed for children and young people to those for adults. It is not the same as transfer between services, which does not involve any adaptation of the service to individual need. Transition, by contrast, is about fitting services around the person, and requires planning a period of change that 'is sensitive to underlying needs, [and] improves health, educational and social outcomes for young people' [11].

The transition process should include a number of key principles (Table 1 [11]), but how they are implemented depends on local service provision and the nature of the long-term physical and medical conditions of the service users. The Royal College of Nursing set out the principles of good practice for developing a transition service [12], noting the cultural difference between children's services (focus on the child and the family) and adult services (focus on the individual or parts of the body). Transition services need to be flexible, based on the needs of the young person, and 


\section{Table 1. Principles of a transition process [11]}

Planning is person-centred and needs-focused, identifying the hopes, aspirations and goals of the young person who plays an active part in decisions about their future

It assesses the likely impact of future health needs and identifies interventions/strategies

It sees transition as a process and develops flexibility in moving to adult services depending on a young person's wishes, needs and developmental readiness

It explores, with young people, opportunities for independent living and developing skills in monitoring/managing their conditions and in developing and improving their self-image

It helps a young person understand how to access adult services and fully engages children's and adult health services in planning for an individual young person

It develops a health plan with the young person, and their family and carers, identifying the most appropriate health professional to coordinate this

It takes account of physical, psychological, social, educational and vocational dimensions, and the need for equipment/adaptations

It observes local information-sharing protocols, taking account of a young person's wishes for confidentiality

It ensures a good working knowledge of the professional roles of the core health transition team as well as those in other agencies

It works closely with other agencies to ensure that the health plan is shared, when appropriate, and incorporated into a young person's broader transition plan (through the statutory review process for those with SEN statements but also for other young people)

It continues to support the young person in their development of adult roles and responsibilities once they have transferred to adult services

It engages both children's and adult health services in identifying areas of unmet need and planning at strategic level

It develops services that reflect the need for a comprehensive transition health team, with specific roles as well as generic competencies

reviewed from their perspective. Planning must be a joint effort, involving service users, their families and the voluntary sector. Providers should review and redesign services to ensure that they meet users' needs, including the use of technology and social media. Children's and adult services should share protocols so that the transition appears seamless to service users, who should be introduced to providers of adult services in advance. Service users should have a key worker or lead professional to plan the transition with them; transition should constitute a significant part of that worker's job description, rather than being a minor addition. Staff should receive training around the developmental and wider social and emotional needs of young people.

Despite the wealth of guidance available, the reality in clinical practice has often been unsatisfactory, [3] and even agencies such as NICE have been inconsistent in their delivery. For example, the NICE 2013 quality standard for the management of epilepsy in children and young people states:

"Young people with epilepsy have an agreed transition period during which their continuing epilepsy care is reviewed jointly by paediatric and adult services," [13].

By contrast, the 2013 quality standard for attention deficit hyperactivity disorder (ADHD), covering diagnosis and management in children, young people and adults, is concerned with ensuring that adults who were diagnosed with ADHD when children should be referred to adult psychiatric services. [14]

In 2012, NHS Diabetes found that, despite ready access to guidance, there was no clear model for what was most effective. Health professionals did not feel they managed transition well enough, and further action was required in terms of what health services actually needed to do to implement a good transition service [8].

NHS England, consulting in 2014 on proposals for services for congenital heart disease, reported that experiences of transition had been unsatisfactory. Young people reported that they had not had enough opportunity for discussion with someone who had experience of congenital heart disease; that they had received too little information and the information that was provided was in an unsuitable format; that there was no opportunity to say goodbye to people in the paediatric service; and that the adult service was unwelcoming [15].

Similar messages emerged from a roundtable meeting of young people with chronic kidney disease and health professionals [16]. In addition, this report emphasised the importance of changes in the relationship between parents and young people during transition. A need for support for parents from peers and health professionals was identified, along with a role for the voluntary sector in providing information, counselling, funding for youth workers, and funding for trips and respite services.

The STEPP project (Supporting health Transitions for young people with life-limiting conditions: researching Evidence of Positive Practice) interviewed children with potentially life-limiting conditions, including cystic fibrosis, renal disease, degenerative neuromuscular conditions, metabolic conditions and cerebral palsy [17]. It found variable practice. Some individuals reported an uneventful transition; however, the majority reported a less pleasant experience. Those 
admitted to adult wards, and their parents, reported a lack of information about differences in the patient population and visiting hours; lack of preparation for the change; lack of specialist experience among general medical and nursing staff; lack of recognition that some young people want parental support when making decisions; lack of overnight facilities for parents; and social isolation.

\section{What is the right age for transition?}

Planning transition for an individual should begin early, though the age at which it occurs should be determined individually. The Children and Families Act 2014 states that children with special educational needs and disability should have an Education, Health and Care (EHC) plan up to age 25 from school year 9 (age 13 - 14) [18].

The National Network of Parent Carer Forums developed a generic transition model in which the concept of transition is introduced at age 12-13 years (school year 8 ) and specific work begins the following year [19]. The STEPP project concluded that an individual transition plan should be developed by age 14 and a rolling plan in place by age 16 [18]. The CQC stated that every young person with complex physical health needs should, from age 14, have a transition plan that meets all their health needs [4], but added:

"What works for one 14-year-old may not work for another because of developmental maturity and their resulting needs. What matters most is that services must be integrated, and care coordinated around the individual, with an optimal experience of transition to adult services for those young people who require ongoing health and care in adult life whatever their age."

In practice, however, the age at which transition occurs may depend on the service rather than the individual [4]. A 2011 US consensus statement on transition for young people with congenital heart disease recommended transition around age 12 , but stated that it should be individualised according to the person's medical and developmental status [20]. A large review of US cystic fibrosis clinics found that first discussion of transition occurred at a median age of 17 with a range 'at the time of diagnosis' to 25; transfer of care occurred at a median of 19 years, with a range of 14-30 years [21]. More recently in Ireland, transition for young people with cystic fibrosis occurred at age $16-18$ for $81 \%,>18$ for $9.5 \%$, and 13-15 for $10 \%$ for individuals with both cystic fibrosis and diabetes [22]. In Canada, a survey of cystic fibrosis clinics found that the age at transition was 18 for $78 \%$ of young people, and 16-19 for the remainder [23]. Analysis of a US patient registry showed that the mean age at transition for young people with cystic fibrosis was 21.1 [24].

Transition occurs at older age for young people with diabetes. In the US, surveys of young people with diabetes and their parents found that their preferred age was 17-18 $[25,26]$, but reported that the mean (or median) ages at which transition occurred were $19.5-20.3$ [27-29]. A survey by the

Table 2. Indicators of good practice for transition services

\begin{tabular}{|c|c|}
\hline Consent and confidentiality & $\begin{array}{l}\text { Explicit or expressed valid consent is obtained and recorded prior to sharing information or providing treatment or } \\
\text { care. } \\
\text { Young people's best interests are maintained where they lack the capacity to make particular decisions. } \\
\text { Confidentiality is maintained by all staff members. }\end{array}$ \\
\hline $\begin{array}{l}\text { People, carer and community } \\
\text { members' participation }\end{array}$ & $\begin{array}{l}\text { Young peoples', parents/carers' and community members' views and choices underpin the development, planning } \\
\text { implementation, evaluation and revision of personalised care and services, and their input is acted upon. } \\
\text { Strategies are used to involve young people and parents/carers from isolated or hard to reach communities. }\end{array}$ \\
\hline Leadership & Effective leadership is in place throughout the organisation. \\
\hline Education and training & $\begin{array}{l}\text { Staff are competent to assess, plan, implement, evaluate and revise care according to all young people's and } \\
\text { parents/carers' individual needs. } \\
\text { Education and training are available and accessed to develop the required competencies of all those delivering } \\
\text { care. } \\
\text { Young people and parents/carers are provided with the knowledge, skills and support to best manage their care. }\end{array}$ \\
\hline Documentation & $\begin{array}{l}\text { Care records are clear, maintained according to relevant guidance and subject to appropriate scrutiny. } \\
\text { Evidence-based policies, procedures, protocols and guidelines for care are up-to-date, clear and utilised. }\end{array}$ \\
\hline Service delivery & $\begin{array}{l}\text { Coordinated, consistent and accessible services exist between health and social care organisations that work in } \\
\text { partnership with other relevant agencies. } \\
\text { Care is integrated with clear and effective communication between organisations, agencies, staff, young people } \\
\text { and parents/carers. } \\
\text { Resources required to deliver care are available. }\end{array}$ \\
\hline Safety & Safety and security of young people, parents/carers and staff is maintained at all times. \\
\hline Safeguarding & $\begin{array}{l}\text { Robust, integrated systems are in place to identify and respond to abuse, harm and neglect. } \\
\text { All agencies working with young people and their families take all reasonable measures to ensure that the risks of } \\
\text { harm to young people's welfare are minimised. }\end{array}$ \\
\hline
\end{tabular}


Table 3. Factors that make up a person-focused outcome of a transition service [33]

\begin{tabular}{|c|c|}
\hline Factor & Best practice \\
\hline $\begin{array}{l}\text { Factor 1: Moving to manage a health condition } \\
\text { as an adult }\end{array}$ & $\begin{array}{l}\text { Young people are offered advice and information in a clear and concise manner about how to } \\
\text { manage their health condition as an adult. }\end{array}$ \\
\hline Factor 2: Support for gradual transition & $\begin{array}{l}\text { The young person, as they progress through the transition process, is gradually prepared and pro- } \\
\text { vided with personally understandable information and support. }\end{array}$ \\
\hline Factor 3: Coordinated child and adult teams & $\begin{array}{l}\text { The young person is supported through a smooth transition by knowledgeable and coordinated } \\
\text { child and adult teams. }\end{array}$ \\
\hline Factor 4: Services 'young people friendly' & $\begin{array}{l}\text { Young people are provided with care in an environment that recognises and respects that they are } \\
\text { a 'young person', not a child or adult. }\end{array}$ \\
\hline Factor 5: Written documentation & $\begin{array}{l}\text { Concise, consistent and clearly written documentation, containing all relevant information about } \\
\text { the young person's transition, is provided to the teams involved in the transition process. }\end{array}$ \\
\hline Factor 6: Parents & $\begin{array}{l}\text { Parents are included in the transition process, gradually transferring responsibility for health to the } \\
\text { young person. }\end{array}$ \\
\hline Factor 7: Assessment of 'readiness' & The young person's readiness for transition to adult care is assessed. \\
\hline Factor 8: Involvement of the GP & $\begin{array}{l}\text { The young person's GP is informed of the plan for transition and is able to liaise with other relevant } \\
\text { teams to facilitate services requested/needed by the young person. }\end{array}$ \\
\hline
\end{tabular}

International Society for Pediatric and Adolescent Diabetes of 92 centres in 36 countries found that 37 per cent looked after young people until the age of 25 , but that these patients also saw adult diabetologists. Structured transition occurred at age $14-25$ in $44 \%$ of centres, and at ages $18-25$ in $45 \%$; one centre reported no age limit [30]. For young people with mental health needs, transition age boundaries reported in published studies range from 16-21 (mode 18) [31].

A survey of 15 UK transition clinics for children and young people with epilepsy showed that the minimum age for referral to the clinic was $14-15$ for 12 clinics, and a younger age for the remainder; the maximum age for referral was 1820 [32]. There appears to be no published data describing the age at transition for children and young people with haemophilia.

\section{What is a 'successful' transition?}

The success of a transition service may be interpreted as the achievement of indicators focused on process or outcomes, such as clinical targets. There is guidance available on how to develop the transition process $[10,11,14]$ but little on measuring outcomes.

For example, the London TRACK study defined optimal transition entirely by process, using criteria derived from an audit of CAMHS (child and adolescent mental health services) transition protocols and literature on good practice in relation to continuity of care [33]. These included information transfer, joint working between CAMHS and adult mental health services during transition, planning prior to transfer, and long-term continuity of care. Qualitative interviews with 11 young people showed that seven felt that their mental health had improved since transition to adult services, though this was not necessarily due to the transition itself.

A consensus statement developed by UK practitioners, children and young people, and their parents includes clear advice on what constitutes good process (see Table 2), but only one person-orientated outcome: 'Young people and their parents/carers experience timely and effective transition' [34]. This outcome comprises eight process 'factors' that characterise optimal transition (Table 3). Guidance to Clinical Commissioning Groups (CCGs) on implementing these arrangements includes recommendations for monitoring outcomes using indicators from the Clinical Commissioning Group Outcomes Indicator Set (Table 4) [35,36]. These are, however, generic measures for monitoring performance: although they apply as much to transition as to any NHS service, they are not specific to it. The NICE Quality Standard on epilepsy includes one outcome for transition - 'Young people's experience of transition to adult services' - but includes advice on measuring process only [13]. What young people say they want from a transition service has been summarised (Table 5), but even this list is concerned with process [2]. It is assumes that current generic guidance on the transition process [8,10-17] reflects the latest evidence on what is optimal, and is not discussed further.

In Quality Criteria for Young People Friendly Health Services, the Department of Health recommended that a transition service should evaluate the experience of young people in part by inviting and encouraging 'all clients to give their opinions of the service offered and whether it met their needs; these are reviewed and acted on as appropriate' [37] Some studies have documented these outcomes as reported by young people or their families (Table A [Appendix]). Other studies have reported clinical outcomes, such as seizure control in people with epilepsy and glycaemic control in people with diabetes.

A recent systematic review of transition in mental health services found a lack of adequately powered studies to evaluate the effectiveness of different transition models, and noted wide variation in emotions and views between service users [38]. Several of the studies cited assessed satisfaction 
Table 4. NHS performance indicators with potential application to a transition service $[34,35]$

Domain 1: Preventing people from dying prematurely

Domain 2: Enhancing quality of life for people with longterm conditions

Domain 3: Helping people to recover from episodes of ill health or following injury

Domain 4: Ensuring that people have a positive experience of care
Indicators suggested for the NHS Outcomes Framework and the CCG OIS by the Children and Young People's Health Outcomes Forum Long-term Conditions, Disability and Palliative Care Subgroup
Overarching indicator on potential years of life lost from causes considered amenable to healthcare for adults

Health-related quality of life for people with long-term conditions

People feeling supported to manage their condition

Unplanned hospitalisation for chronic ambulatory care-sensitive conditions (adults)

Unplanned hospitalisation for asthma, diabetes and epilepsy in under-19s

Emergency admissions for acute conditions that should not usually require hospital admission

Emergency readmissions within 30 days of discharge from hospital

Emergency admissions for children with lower respiratory tract infections

Patient experience of GP out-of-hours services

Patient experience of hospital care

Friends and family test for acute inpatient care and A\&E

Improving people's experience of outpatient care

Improving hospitals' responsiveness to personal needs

Improving women and their families' experience of maternity services

Improving the experience of care for people at the end of their lives

Improving experience of healthcare for people with mental illness

Improving children's and young people's experience of healthcare

Improving people's experience of accident and emergency services

Improving people's experience of integrated care

Getting a quality multidisciplinary assessment that reflects all the child's or young person's needs, in addition to those of their family.

Getting a quality package of care (including a healthcare plan for emergency situations or an end-of-life care plan where appropriate), fully integrated across health, education and social care, with access to key working support, information to enable the child or young person and family to manage the condition, and timely provision of equipment to support maximum participation.

Ensuring review of the care plan at key points of transition, particularly transition to adult life and services.

Ensuring that the outcome indicators promote a whole family approach, because the health and wellbeing of family (carers) directly impacts on children and young people and their resilience. with transition arrangements: the proportion of people reporting positive satisfaction ranged from 57 to $94 \%$, and dissatisfaction from 3 to $20 \%$. In young people with diabetes, a sense of loss on transition was more common among those with superior glycaemic control, suggesting that differences in the clinical quality of paediatric and adult services can be an important influence on perceptions of transition.

Several studies compared pre- and post-transition responses from service users and their families. No difference in health-related quality of life was reported by young people with haemophilia, though fathers rated the post-transition quality of life of their children as worse [39]. In one study, young people with cystic fibrosis rated adult services superior to paediatric services [40]. Comparing the views of pre-transition adolescents with cystic fibrosis and their families with the views of post-transition adults, satisfaction with the transition process was high; however, there was no relationship between the degree of involvement in the transition process and measures of quality of life, lung function or body mass index [41].

Most of the studies that have evaluated transfer to adult services by young people with type 1 diabetes have included glycaemic control as an endpoint. Several report no difference in glycaemic control before and after transition [42-44]. Of those comparing groups who had been through transition with others transferred with no

\section{Table 5. What young people say they want from a transition service [2]}

Active management of transition: consider the timing; plan early and prepare for leaving children's services and arriving at the adult service

Take into account how attitudes, thinking and behaviour vary between individual young people.

Involve young people in service design and delivery: provide opportunities for young people to ask questions, express opinions and make decisions

Provide accessible information about services; share information between services; ensure multi-agency working, coordination and accountability across different organisations within the public sector and voluntary organisations

Stress the importance of a trusted adult who can challenge and support them, act as advocate and help them to develop self-advocacy skills

Establish a shared philosophy between adult and paediatric care

Adopt an individualised, honest approach

Address loss of continuity of care at transition; ensure new relationships are established

Train professionals in adolescent health in both paediatric and adult sectors

support programme, one reported that glycaemic control was improved after transition and one year later, but that after three years there was no advantage over unstructured transfer [45]. A second study found no association between transition preparation and post-transition glycaemic 
Table 6. Tools to measure person-centred outcomes

\begin{tabular}{|c|c|c|}
\hline Study & Client group & Tools \\
\hline Geerts E et al39 & $\begin{array}{l}\text { Young people with haemophilia and their parents, } \\
\text { paediatric haemophilia centres, The Netherlands }\end{array}$ & $\begin{array}{l}\text { Worry: } \\
\text { Johns Hopkins Adult Cystic Fibrosis Program survey } \\
5 \text { - point Likert scale } \\
\text { Quality of life } \\
\text { Haemo-QoL-A } \\
\text { Parental illness-related stress } \\
\text { Adapted from questionnaire for children with cancer }\end{array}$ \\
\hline Mackie et al48 & $\begin{array}{l}15 \text { - } 17 \text { year-olds with moderate or complex } \\
\text { congenital heart disease (CHD) or cardiomyopathy }\end{array}$ & $\begin{array}{l}\text { Readiness: } \\
\text { Transition Readiness Assessment Questionnaire } \\
\text { Knowledge: } \\
\text { MyHeart scale }\end{array}$ \\
\hline Huang JS et al49 & Adolescents with chronic disease aged $12 \otimes 20$ & $\begin{array}{l}\text { Disease status: } \\
\text { Pediatric Ulcerative Colitis/Crohn's Disease Activity Index } \\
\text { Cystic Fibrosis Clinical Score } \\
\text { Diabetes Quality of Life Brief Clinical Inventory } \\
\text { Health literacy: } \\
\text { Test of Functional Health Literacy in Adults } \\
\text { Disease management and self-efficacy: } \\
\text { Transition Readiness Assessment Questionnaire } \\
\text { Patient Activation Measure }\end{array}$ \\
\hline $\begin{array}{l}\text { Steinkamp G et } \\
\text { al40 }\end{array}$ & 44 people with cystic fibrosis aged $18 \otimes 33$ & $\begin{array}{l}\text { Service user experience: } \\
\text { Specifically developed questionnaire }\end{array}$ \\
\hline $\begin{array}{l}\text { Chaudhry SR et } \\
\text { al53 }\end{array}$ & Adults attending cystic fibrosis centre & $\begin{array}{l}\text { Service user experience: } \\
\text { Specifically developed questionnaire }\end{array}$ \\
\hline Craig SL et al41 & $\begin{array}{l}\text { Pre-transition adolescents and their parents and a } \\
\text { 'post-transition' group who had moved on over a } \\
\text { six year period }\end{array}$ & $\begin{array}{l}\text { Participant concerns: } \\
\text { Transition to Adult Care Concerns Questionnaire developed by the } \\
\text { researchers from CF Transition Survey and using a Likert scale } \\
\text { Participation in transition: } \\
\text { Cystic fibrosis transition questionnaire } \\
\text { Satisfaction: } \\
\text { Transition to Adult Care Concerns Questionnaire } \\
\text { Health-related quality of life: } \\
\text { Cystic fibrosis questionnaire }\end{array}$ \\
\hline $\begin{array}{l}\text { Markowitz JT et } \\
\text { al43 }\end{array}$ & Support group for young adults with type 1 diabetes & $\begin{array}{l}\text { Burden of illness: } \\
\text { Problem Areas in Diabetes survey } \\
\text { Self-care } \\
\text { Self-Care Inventory-R } \\
\text { Preferences } \\
\text { Direct questioning }\end{array}$ \\
\hline Cadario F et al45 & $\begin{array}{l}\text { Adolescents and young adults with type } 1 \text { diabetes } \\
\text { transferred in unstructured way or through a } \\
\text { transition programme }\end{array}$ & $\begin{array}{l}\text { Feelings about service } \\
\text { Direct question requiring categorical response (good, sufficient, bad) }\end{array}$ \\
\hline
\end{tabular}

control [46]. A systematic review evaluating the impact of various transition models on ten young people with diabetes found that six reported improved post-transition glycaemic control and four reported no change [47]. However, the reviewers noted a lack of adequate controls and comparators.

This review also found that other post-transition outcomes were mixed. The process of transition was rated at least satisfactory by 57 to $94 \%$ of participants and unsatisfactory by 3 to $20 \%$. Service users described a sense of loss or abandonment when relationships with staff in paediatric services ended.

Some studies have prospectively compared transition arrangements with usual care (i.e. a less supportive transfer to adult services). In young people with congenital heart disease or cardiomyopathy, knowledge and transfer readiness were more improved after six months by a nurse-led transition process than among controls [48]. A two-month web-based transition programme focusing on disease management was compared with usual care in a group of 12-20 year-olds with various long-term conditions [49]. After six months, programme recipients had superior self-management skills and health-related self-efficacy, and initiated more communications with the care team. However, the groups did not differ in disease status, quality of life or functional performance. A prospective study of young people with diabetes who were leaving paediatric services found no differences in glycaemic control, complications, admissions to hospital, service retention or global self-worth between those who had gone through a transition programme with others who received usual care [50].

A retrospective review of US community-based transition 
Table 7. Transition models for young people with cancer [66]

\begin{tabular}{|c|c|c|}
\hline & Health-Oriented Transition & Crisis-Oriented Transition \\
\hline Defining characteristic & $\begin{array}{l}\text { - Involves transition of long-term follow-up } \\
\text { monitoring and management of some chronic } \\
\text { late effects }\end{array}$ & $\begin{array}{l}\text { - Involves transition of treatment for recently diagnosed } \\
\text { recurrent, secondary or primary malignancy }\end{array}$ \\
\hline Timing & $\begin{array}{l}\text { - Is anticipated well in advance with flexibility } \\
\text { in timing }\end{array}$ & - Is unanticipated and urgent \\
\hline \multirow[t]{4}{*}{ Key Interventions } & $\begin{array}{l}\text { - Preparation of comprehensive clinical } \\
\text { summary with management recommendations, } \\
\text { shared with patient and adult providers }\end{array}$ & - Immediate education of patient and family on adult system \\
\hline & $\begin{array}{l}\text { - Development and use of 'transition skills } \\
\text { training programs' to assist survivors in } \\
\text { addressing education, employment, and } \\
\text { insurance issues }\end{array}$ & $\begin{array}{l}\text { - Immediate linking with specific, age-appropriate supports in } \\
\text { adult setting }\end{array}$ \\
\hline & $\begin{array}{l}\text { - Maintain contact with survivors and providers } \\
\text { to provide updated care recommendations and } \\
\text { to serve as information resource }\end{array}$ & $\begin{array}{l}\text { - Temporary assignment of 'care buddy' from pediatric team to } \\
\text { accompany patient to initial tests and treatments }\end{array}$ \\
\hline & & $\begin{array}{l}\text { - Continued consultative involvement of pediatric team to } \\
\text { assist in adult care setting, as indicated }\end{array}$ \\
\hline
\end{tabular}

programmes for young people with mental health problems concluded that, compared with historical or baseline outcomes, employment, education, criminality, substance use and productivity had all improved over a four-year period [51]. Also in the US, an evaluation of transitional pathways in 22 young people with cystic fibrosis concluded that, though predominantly concerned with improving adherence to process, the pathways were associated with increased transfer readiness and improved knowledge about cystic fibrosis [52]. A cross-sectional study compared outcomes in young people with cystic fibrosis who had or had not participated in a transition programme [53]. Participants reported higher levels of satisfaction and perceived health status before but not after transfer to adult services; there were no other differences between the groups.

This overview shows that some studies have evaluated person-centred outcomes of the transition process, and have found that a majority of users express satisfaction with process and demonstrate improved knowledge and self-efficacy. However, there is little or no evidence that a transition programme improves quality of life scores, and there is little consistent evidence of an improvement in clinical outcomes. This lack of evidence can be attributed in part to the variability in study design and the often small populations under evaluation [38,47]. The positive (or negative) effect of a transition programme can therefore not be excluded.

\section{Tools for measuring person-centred outcomes}

Table 6 lists the tools that have been used in published studies to assess person-centred outcomes, such as satisfaction and quality of life. Some are specific to the medical condition, some were developed specifically for the study, and others are generic tools. The available studies do not provide sufficient information on which to base the selection of an appropriate tool specifically to assess a transition service. Conversely, several studies have used tools that can be applied in a range of settings, with the implication that tools validated for other purposes may be appropriate.

\section{What characterises a transition that changes health outcomes?}

Some studies have shown that a transition programme can influence health outcomes, but this is not a consistent finding $[38,47]$. Improvement in health has also been reported after transfer from paediatric to adult services without specific documentation of a formal transition programme [24].

A 2014 systematic review of transitional care in mental health services identified three studies, all from the US, reporting change in health outcomes after transition (Table $B$ [Appendix]) [38]. None of these publications describes the mix of health disciplines and training required to deliver the services.

The Partnerships for Youth Transition (PYT) initiative was a demonstration project comprising community-based transition support programmes for transition-age youth and young adults, aged 14-21 years, with serious mental health conditions [51]. PYT developed models for transition support services based on a single service model: the Transition to Independence Process (TIP) model developed in Florida. In community settings, a locally driven, collaborative planning process was used which involved a broad range of stakeholders, including service users, their families and other members of their natural support networks, direct care providers, administrators, community leaders, and other community representatives. Each programme had flexibility with regard to which types of interventions it used, but all were required to develop strategic plans, logic models and programme manuals in collaboration with their stakeholders. All had the support of the National Center on Youth Transition for Behavioral Health to develop their programmes, using published guidelines and other literature to guide best practice. 
The introduction of transition programmes specifically to support young people with mental health needs aged 18-24 years increased outpatient visits but had no effect on inpatient admissions, use of emergency services or days receiving care while in custody [54]. The programme applied the psychiatric rehabilitation model used for older people in physical and organisational settings more suitable for young adults, such as agencies within the child care system, staff experienced with youth work and age-appropriate skills. The rehabilitation model focused on competency, recovery and empowerment using social, educational, occupational, behavioural and cognitive interventions to support longterm recovery and independence.

The third study described the development of services for young adults with psychosexual behaviour problems, other high risk behaviours and psychiatric symptoms [55]. The model of care was based on the belief that such behaviours have a basis in childhood trauma and disruption of attachments. Services were comprehensive and integrated, and based on the dynamic assessment of individual needs and preferences. Service delivery incorporated clinical, residential, case management and other support services to help service users develop social support systems, achieve success at school and cope with early employment. If necessary, services were available 24 hours a day, 7 days a week.

Several studies document positive health outcomes associated with participation in a transition programme for young people with diabetes (Table B) [44,45,56-58]. In a retrospective comparison of unstructured and structured transfer to adult services within a hospital delivering the paediatric service, glycaemic control improved after structured transfer but deteriorated after unstructured transfer [45]. The structured programme was designed for patients aged $18-20$ years. The timing of transfer was flexible in order to accommodate personal circumstances, and patients were supported by a single transition coordinator with specialist training. The process and implications of transition were explained verbally in the last year of the paediatric service and repeated in writing. All patients were guaranteed continuous individual support and the possibility of a return to paediatric service if they preferred. The last paediatric appointment and the first adult appointment were held jointly with the adult endocrinologist in the absence of the parents. Younger patients were considered separately from older patients in the first year in adult services.

In Belfast, young people of school-leaving age with diabetes who were considered suitable for transfer to adult services were offered a bimonthly Saturday morning clinic (specifically set up for 16 - 25 year-olds) or routine weekday appointments in the adult clinic [56]. An adult physician attended the paediatric clinic on a monthly basis, at which patients ready to transfer were identified. Transfer was usually encouraged at the time of leaving school, whatever age this occurred. Data for 18 patients aged $14-24$ who attended the Saturday clinic and 15 who attended the adult clinic, audited from two years before transfer and $15-18$ months afterwards, showed a trend to improved glycaemic control and somewhat improved attendance. Differences between the two clinics were not reported.

An audit of a transition clinic in Newcastle demonstrated improved glycaemic control in young people [57]. Transition was a two-stage process, with a year's co-working of joint paediatric and adult teams, followed by a monthly young adult clinic held in the evening. The team comprised a consultant diabetologist, a specialist diabetes nurse, a specialist registrar, a specialist dietitian and a clinical psychologist, each with a special interest in adolescent diabetes. Minimal rotation of staff ensured continuity of care. The last three appointments in the paediatric service were attended by the paediatric and adult physicians and held in the adult service premises. The age at transition was usually 17-18 years, but adjusted according to individual maturity, development and personal circumstances. An annual focus group of service users provided feedback.

The transition service offered evening clinics so that young people did not have to sit with older people with diabetes who had developed complications. Review, follow-up and education were delivered within three appointments per year; participants were not willing to attend more meetings. Social change, diet and activities were reviewed in groups. Patients could opt to see only a particular member of the team during appointments, with the exception of their annual full assessment. Of the 38 referrals described, 28 patients saw a clinical psychologist, with 21 doing so more than once. After each appointment, a letter summarising the outcomes and the agreed plan was sent directly to the young person and copied to their GP.

In Australia, participation in a transition programme improved glycaemic control and reduced admissions due to acute complications in young people with diabetes [44]. This programme was essentially an appointments service, comprising a reminder system for appointments and rebooking of missed appointments, and an after-hours phone support service. Young adults aged $15-25$ years with type 1 diabetes were referred to the programme by either a specialist or primary care physician, and seen in a young adult diabetes clinic based in the adult hospital. Young people admitted with diabetic ketoacidosis were also referred. The programme was run by a transition coordinator, who was a qualified diabetes educator and attended the young adult clinic alongside a diabetes specialist, a dietician and a second diabetes educator. Reminders were sent before each clinic via phone calls, text messaging and email; missed appointments were rebooked after talking to the young person. The aim was to ensure at least two visits per year.

A 'transition therapeutic education programme' was 
Table 8. Content of a nurse-led transition programme for young people with congenital heart disease of cardiomyopathy [48]

Introduction to transition and its importance

Discussion of confidentiality and what that means to promote trust with study nurse

Creation of a MyHealth passport, including

- $\quad$ name of cardiac condition

- $\quad$ previous cardiac interventions

- $\quad$ name and purpose of medications

- $\quad$ need for endocarditis prophylaxis (yes/no)

Review diagram of cardiac anatomy ( participant-specific)

Discussion of three potential future cardiac complications (participant-specific)

Review contact names and location of local adult congenital heart disease cardiologists

Introduction to relevant websites

Discussion of three brief third-person scenarios addressing alcohol, smoking/street drugs and sexuality/contraception

Introduce youth-oriented take-home written materials (sexually transmitted infections, substance abuse)

Provide study email address and study cell number, and encourage follow-up emails or text messages with study nurse

associated with improved glycaemic control, fewer acute complications and improved self-knowledge in young people with diabetes who were transferring from a paediatric to an adult service [58]. The programme included coordinated transfer between the paediatric and adult diabetes unit. Patients and their families were assessed for insulin use, metabolic control, self-management and knowledge of diabetes, weight and quality of life. Patients agreed a schedule for insulin injections and treatment goals. Education and support was delivered via group sessions, and between three and six visits were provided over a period of 3-6 months.

In summary, there are surprisingly few examples of transition programmes shown to improve health outcomes for the disorders selected for this literature review. The examples of programmes for young people attending mental health services or with diabetes do not provide a full account of the programme content or its delivery (e.g. the involvement of different health professionals). They do show that health outcomes can be improved by adapting services in different ways, whether through dedicated resources (e.g. premises for young people only), emotional and psychological support (e.g. an extended handover between paediatricians and adult clinicians) or providing practical support (e.g. reminders).

Transition programmes for young people with other longterm conditions have been shown to improve outcomes. For example, an integrated paediatric-young adult joint transition clinic and care pathway for young people with a kidney transplant was associated with no graft loss in 12 patients, compared with 6 of 9 in historical controls [59]. The transition programme included joint medical clinics at the paediatric centres staffed by a paediatric and adult nephrologists and renal transplant nurses, with a youth worker from the adult team. The clinics were four-monthly and attended by patients aged 15-18 years; transfer to the adult clinic occurred by the age of 18 years by mutual consent of the patient, family, and the paediatric and adult clinical teams. Young people were seen both alone, to promote autonomy, and with their families. Before transfer, the youth worker provided at least one community visit and the young person visited the adult unit. A Canadian study reported that a multidisciplinary transition clinic for young people with a kidney transplant was associated with no graft loss, compared with $24 \%$ in historical controls, and that the service was cost-effective compared with unstructured transfer [60].

\section{Does morbidity affect the process or outcome of transition?}

The importance of morbidity as a factor in the outcome of transition has not been extensively investigated. Long-term conditions are associated with different morbidities and their severity and frequency vary, as does their impact on the individual and services.

In young mental health service users undergoing transition, those with mood or learning disorders had better outcomes than those with disruptive behaviour disorders; this may have been due to easier engagement with the programme [51]. In patients with diabetes, the rate of improvement in glycaemic control $(\mathrm{HbA} 1 \mathrm{C})$ was similar for individuals referred to a transition programme by a GP or specialist and for those referred after admission for diabetic ketoacidosis [44]. In young people with epilepsy, successful transfer to adult care was associated with a stable condition before transfer (although this study did not describe a transition programme) [61]. In patients with diabetes, participation in a transition programme was lower among those with poor glycaemic control prior to transfer than in individuals with better control [56]. In a US study in children with systemic lupus erythematosus, transition difficulties due to loss of insurance and emotional readjustment were associated with poor symptom control and multiple organ system involvement [62]. By contrast, in children with spina bifida there was no association between the time required for transition and active clinical problems, such as urinary incontinence or urinary interventions [63]. In young people living with HIV, severity (as indicated by CD4 count or viral load) did not correlate with objectively assessed readiness for transition [64]. Surprisingly, among young people with sickle cell disease, a risk factor for unsuccessful transition from paediatric to adult services was milder disease severity (as denoted by genotypes associated with milder disease and absence of chronic transfusion therapy) [65].

A review of transfer to adult services by young people with cancer proposed two models of transition programme, one health-oriented model and one crisis-oriented (Table 7) [66]. The health-oriented model would be suitable for 
Table 9. Content-based framework to aid selection of outcome measures for interventions to promote self-management in young people with long-term conditions [79]

\begin{tabular}{|l|l|l|}
\hline Medical management & Role management & \multicolumn{1}{l}{ Emotion management } \\
\hline Health outcomes & Health outcomes & Psychological outcomes \\
Knowledge of the disorder/treatment & General self-efficacy or sense of control & Coping \\
Disease-related self-efficacy & Social participation & Attude towards illness \\
Eelf-care & Vocational participation & Conal aspects of health-related quality of \\
Family involvement/conflict in disease-related & Coping & Psychosocial functioning \\
tasks & Family involvement/conflict in disease- \\
Problem-solving & related tasks & \\
Physical aspects of health-related quality of life & Problem-solving & \\
& Support by others \\
& Social aspects of health-related quality of & \\
& life & \\
\hline
\end{tabular}

those who were well at the time of transition, with the aim of implementing effective processes for continuity of care, developing self-management skills and monitoring in the long term. The crisis-oriented transition would be suitable for children with active disease, who had relapsed at the time of transition, or who were newly referred to a paediatric service but for whom an adult service was more appropriate. This approach was characterised by urgency and the need for rapid education of the patient and family, immediate engagement with adult services, personal support during the time of transition and ongoing involvement of the paediatric team.

Readiness for transition can be determined using an assessment tool. A systematic review of generic and disease-specific tools concluded that they generally lacked validity; none of the ten tools selected for review included symptoms or disease severity in their criteria [67].

Taken together, these studies suggest that morbidity may or may not affect transition, but there is little information regarding the causes of difficulties in engaging with care processes. The structure and content of a transition programme can be adapted to meet the differing needs of individuals, but there is a lack of evidence on how to assess readiness for transition in such cases.

\section{Nurse leadership in transition}

The role of a lead nurse in the NHS has been defined as:

"The lead nurse provides professional leadership for nurses, ensuring maintenance of clinical excellence.

Nurses in this role will:

- assess, plan, implement and evaluate nursing care at an advanced level in an unpredictable environment

- work as an autonomous practitioner in managing a clinical caseload;

- undertake research and audit in a specialist area;

- delegate care and responsibilities to other team members and supervise appropriately;

- develop a culture of learning by mentoring, supervising and teaching registered and unregistered staff and students;

- facilitate learning opportunities and conducts appraisals and performance reviews;

- support others in their development of autonomous practice."[68].

The Royal College of Nursing recommended designating a key worker or lead professional to work with a young person, their family and relevant services to plan transition, noting that adolescent nurse specialists have an important role in transition arrangements and, in the absence of a designated leader, are 'often the key professional in making the transition work successfully' [12].

The function of a transition nurse coordinator for young people with complex health needs has been described as acting as a key worker with an overarching view throughout the young person's transition process and [69]

- facilitating the transfer of healthcare from paediatric to adult services;

- working collaboratively with health services in acute and community sectors, hospices, social care, education and voluntary agencies;

- acting as a resource on healthcare matters to families and multi-agency teams

- acting as a health advocate for young people;

- identifying and addressing the training needs of the receiving adult service to enable the health needs of the young person to be met appropriately;

- identifying and highlighting 'gaps' in services to commissioners.

\section{Does nurse leadership facilitate successful transition and improve outcomes?}

No study was identified that compared a transition clinic led by a nurse with that led by a different health professional, though there are accounts of the beneficial effects of nurse-led clinics. There has been little or no attention to the composition of the teams delivering transition programmes. Most published studies of transition do not describe the roles of participating health professionals fully, and there are likely to be unreported differences between studies in the roles of team members.

No published evidence was found on the role of nurses in 
Table 10. Recommendations for practice and organisation change in studies of self-management in the context of transition services

\begin{tabular}{|c|c|c|}
\hline Study & $\begin{array}{l}\text { Long term condi- } \\
\text { tion }\end{array}$ & Recommendations \\
\hline Gray et al, 2015 [76] & $\begin{array}{l}\text { Inflammatory bowel } \\
\text { disease }\end{array}$ & $\begin{array}{l}\text { Separate patients and parents during clinic visits } \\
\text { Hold adolescents accountable for their care } \\
\text { Teach parents how to let go and support their children } \\
\text { Provide patients and parents with more information about transfer and adult providers } \\
\text { Provide patients and parents with feedback from service users } \\
\text { Be deadline-driven when it comes to transfer, but do it during a time of stability }\end{array}$ \\
\hline Gray et al, 2015 [83] & $\begin{array}{l}\text { Inflammatory bowel } \\
\text { disease }\end{array}$ & $\begin{array}{l}\text { Data-driven assessment (e.g. Transition Readiness Assessment Questionnaire) to guide inter- } \\
\text { ventions to enhance transition }\end{array}$ \\
\hline $\begin{array}{l}\text { Plevinsky et al, } 2015 \\
\text { [83] }\end{array}$ & $\begin{array}{l}\text { Inflammatory bowel } \\
\text { disease }\end{array}$ & $\begin{array}{l}\text { Extra education and self-management strategies for patients diagnosed at a young age } \\
\text { Assess post-transition experience to inform transition programme }\end{array}$ \\
\hline Gravelle et al, 2015 [97] & Cystic fibrosis & $\begin{array}{l}\text { Patient transition clinical pathway } \\
\text { Collaboration with the adult clinic } \\
\text { Use of a tool to measure transfer readiness }\end{array}$ \\
\hline Asp et al, 2015 [86] & $\begin{array}{l}\text { Congenital heart } \\
\text { disease }\end{array}$ & Structured and gradual transfer process \\
\hline Heery et al, 2015 [75] & $\begin{array}{l}\text { Congenital heart } \\
\text { disease }\end{array}$ & $\begin{array}{l}\text { Education throughout adolescence about implications of long-term condition, differences } \\
\text { between adult and paediatric services, and self-management }\end{array}$ \\
\hline $\begin{array}{l}\text { Gibson-Scipio et al, } \\
2015 \text { [87] }\end{array}$ & Asthma & Guided support to achieve short- and long-term goals \\
\hline $\begin{array}{l}\text { Gorter et al, BMJ Open } \\
2015[88]\end{array}$ & $\begin{array}{l}\text { Chronic health } \\
\text { conditions }\end{array}$ & $\begin{array}{l}\text { Tailored, integrated and carefully timed support } \\
\text { Individualised goal-setting }\end{array}$ \\
\hline Ferris et al, 2015 [89] & $\begin{array}{l}\text { End-stage kidney } \\
\text { disease }\end{array}$ & Customise self-management and healthcare transition skills \\
\hline $\begin{array}{l}\text { Sheehan et } a_{;}, 2014 \\
\text { [47] }\end{array}$ & Diabetes & Structured transition programme \\
\hline $\begin{array}{l}\text { Annunziato et al, } 2015 \\
\text { [90 }\end{array}$ & Transplantation & Consider mental health screening \\
\hline Mitchell et al, 2015 [9] & Disability & $\begin{array}{l}\text { Involve young people at an early stage } \\
\text { Foster self-advocacy skills and supportive social networks }\end{array}$ \\
\hline van Staa et al 2014 [92] & $\begin{array}{l}\text { Long-term condi- } \\
\text { tions }\end{array}$ & $\begin{array}{l}\text { Early involvement } \\
\text { Collaboration with adult care }\end{array}$ \\
\hline Molter et al, 2015 [93] & Sickle cell disease & Improve low self-efficacy \\
\hline $\begin{array}{l}\text { Javalkar et al, Soc } 2014 \\
{[94]}\end{array}$ & $\begin{array}{l}\text { Chronic kidney } \\
\text { disease }\end{array}$ & Individualised education plan \\
\hline $\begin{array}{l}\text { Fernandes et al, } 2014 \\
\text { [95] }\end{array}$ & $\begin{array}{l}\text { Long-term condi- } \\
\text { tions }\end{array}$ & Standardise transition education to ensure all patients receive necessary information \\
\hline Huang et al, 2014 [49] & $\begin{array}{l}\text { Long-term condi- } \\
\text { tions }\end{array}$ & $\begin{array}{l}\text { Web-based education is effective } \\
\text { Generic approach is cost-effective }\end{array}$ \\
\hline Mackie et al, 2014 [48] & $\begin{array}{l}\text { Congenital heart } \\
\text { disease, cardiomy- } \\
\text { opathy }\end{array}$ & One-hour nurse education is effective \\
\hline Hilliard et al, 2014 [26] & Diabetes & $\begin{array}{l}\text { Standardise transition programme } \\
\text { Transition-oriented clinics for older adolescents and young adults }\end{array}$ \\
\hline Hanna et al, 2013 [96] & Diabetes & Diabetes-specific self-efficacy is important for management \\
\hline
\end{tabular}

transition programmes for young people with haemophilia.

NHS Diabetes noted that the Best Practice Tariff included a recommendation that a nurse was one of three health professionals as a minimum requirement for a transition programme [8]. The document cites the transition programme used by Leeds Teaching Hospitals NHS Trust as an example of best practice. This comprises a transition clinic held at the same time as a young adult clinic; monthly appointments and more frequent contact with a named nurse is available when diabetes control is poor or other problems affect diabetes management. The paediatric team identified the need for a nurse lead.

A survey of UK transition services for young people with epilepsy found that one of 15 clinics included was supervised by paediatric and adult epilepsy nurse specialists without any medical input [32]. In one centre (presumably 


\section{Patient self-management}

The Department of Health defined self-care (taken to be synonymous with self-management) as:

"The care taken by individuals towards their own health and well being, and includes the care extended to their children, family, friends and others in neighbourhoods and local communities.

"Self-care includes the actions people take for themselves, their children and their families to stay fit and maintain good physical and mental health; meet social and psychological needs; prevent illness or accidents; care for minor ailments and long-term conditions; and maintain health and wellbeing after an acute illness or discharge from hospital." [78]

A systematic review of self-management interventions for young people with chronic conditions (not only those undergoing transition) found a focus on medical management, neglecting emotional factors, variation in outcomes measured, and a lack of theoretical underpinning [79]. The reviewers suggest that this casts doubt on how well published studies can be generalised. The review proposes a 'content-based framework' to aid selection of outcome measures (Table 9).

\section{Do patients take responsibility for self-managing their condition?}

It is government policy to encourage people with a longterm condition to take control of their care [80]. In the context of transition, self-management is recognised as an important contributor to a young person's readiness to transfer to adult services [81].

Potential barriers to successful transition in young people with inflammatory bowel disease, congenital heart disease or diabetes include lack of knowledge about their condition, but also a lack of concern about transfer [75] reliance on parental management of their condition and reluctance on the part of parents to relinquish control $[47,76]$ and young age at diagnosis [77]. A 2006 study of young people with haemophilia found, in a group of 108 people who assumed responsibility for self-treatment at a mean age of 14 , almost a quarter still needed parental help at a mean age of 17 [82]. In 195 children and young people with inflammatory bowel disease, fewer than $6 \%$ met a defined threshold for readiness to transfer according to an assessment tool; deficits included scheduling appointments and filling and reordering prescriptions [83].

However, transition readiness may be low even among young people who are well [84] in this study, due to lack of preparation, inability to navigate the health system and lack of health knowledge (including names of medication).

Two trials have assessed the impact of a transition intervention on outcomes including self-management and transition. In the first study, 81 young people with a longterm condition were randomised to usual care or a generic two-month intervention on disease management skills [48]. After six months, disease management skills, health-related self-efficacy and communication with health providers were being carried out by significantly more of the intervention group than the controls. Overall mean adherence to the intervention was $71 \%$. In the second study, 58 adolescents with moderate or complex congenital heart disease or cardiomyopathy were randomised to receive usual care or a one-hour nurse-led individual teaching session about their heart [49]. The primary outcome was transition readiness, as assessed by the Transition Readiness Assessment Questionnaire. After six months, the intervention had significantly increased transition readiness and knowledge about the heart when compared with controls.

A third study, in young people with cystic fibrosis, found that an educational programme to improve transition awareness did not significantly improve self-management skills or selfadvocacy and communication with health providers, when comparing pre- and post-transition assessments [85].

\section{Does self-management promote concordance with an agreed management plan?}

No relevant studies were identified.

What changes in working practices at an individual and organisational level support successful self-management? Table 10 summarises the key points made by authors of studies of self-management in the context of transition to adult services for young people with a range of long-term conditions. Most recommend support and education in one form or another, which should be long-term, individualised and structured. There are no comparisons of the method of delivering an intervention service.

Taken together with the preceding discussion, this data suggests that a specialist key worker providing a transition service should offer young people a supportive relationship of sufficient duration to span a period before and after transfer, and provide education and emotional support to develop self-management and self-efficacy. This role may be carried out by a nurse with appropriate clinical experience, but there is no evidence to show that it should be, provided suitable training is given. The organisation should ensure that the care pathway for young people includes a transition plan introduced at an early stage, with provision of a clinic in an appropriate setting (e.g. a dedicated clinic in the same building as an adult clinic) to ensure access to both paediatric and adult clinicians. As part of this, the threshold for transfer to the adult service should include demonstration of an adequate level of self-management, perhaps using a readiness assessment tool. It therefore follows that the transition clinic should have sufficient capacity and resources to accommodate individuals of 
the nurse-led one), paediatric and adult epilepsy nurse specialists supervised transition, with medical staff providing a detailed written summary. There was no evidence to show whether this affected outcomes in this service.

An evaluation of a nurse-led transition clinic for young people with epilepsy in Canada reported a positive patientfocused outcome: it found that $97 \%$ of female adolescents, all male adolescents and 95\% of caregivers agreed or strongly agreed that the transition appointment lessened fears associated with moving to the adult programme [70]. All young people and caregivers rated nurses highly as appropriate clinic leads. In this programme, nurses from the adult and paediatric services met service users jointly for an initial interview, were among the team responsible for clinical care, and met service users again two to three months later, together with a specialist in adult epilepsy.

A prospective comparison of usual care and a nurseled transition process for 15-17 year-olds with moderate or complex congenital heart disease or cardiomyopathy found that the transition intervention significantly improved self-management and cardiac knowledge scores measured after six months [48]. The transition intervention comprised a one-hour personal interview; the content is summarised in Table 8.

\section{Nurse leadership versus nurse management of the transition process}

No relevant publications were identified.

\section{What changes in working practices at an individual and organisational level will support nurse leadership in transition?}

There is little specific to nursing in published guidance on developing a transition service. In general, no distinction is made between health professions. The emphasis is on process, ensuring that staff have the necessary skills and that an organisation's structure can deliver the required outcomes [4,12]. For example, current NHS guidance on commissioning a transition service for young people with mental health problems does not specify a single optimal staffing structure [71]. This document cites several examples of good practice which show the value of multidisciplinary teams and key designated workers. There is a consensus that service users should be offered support from a single, named individual. Benchmarks for Transition from Child to Adult Health Services, a practice guide to support transitional care developed with young people, parents and professionals, recommends a keyworker/clinical nurse specialist to coordinate care and liaise with the intra- and multidisciplinary team as an indicator of best practice when building a coordinated child and adult team [34].

In relation to structure, guidance generally suggests that services should be delivered in a holistic way that can be adapted to individual need, rather than be limited by arbitrary age and interdisciplinary boundaries. The

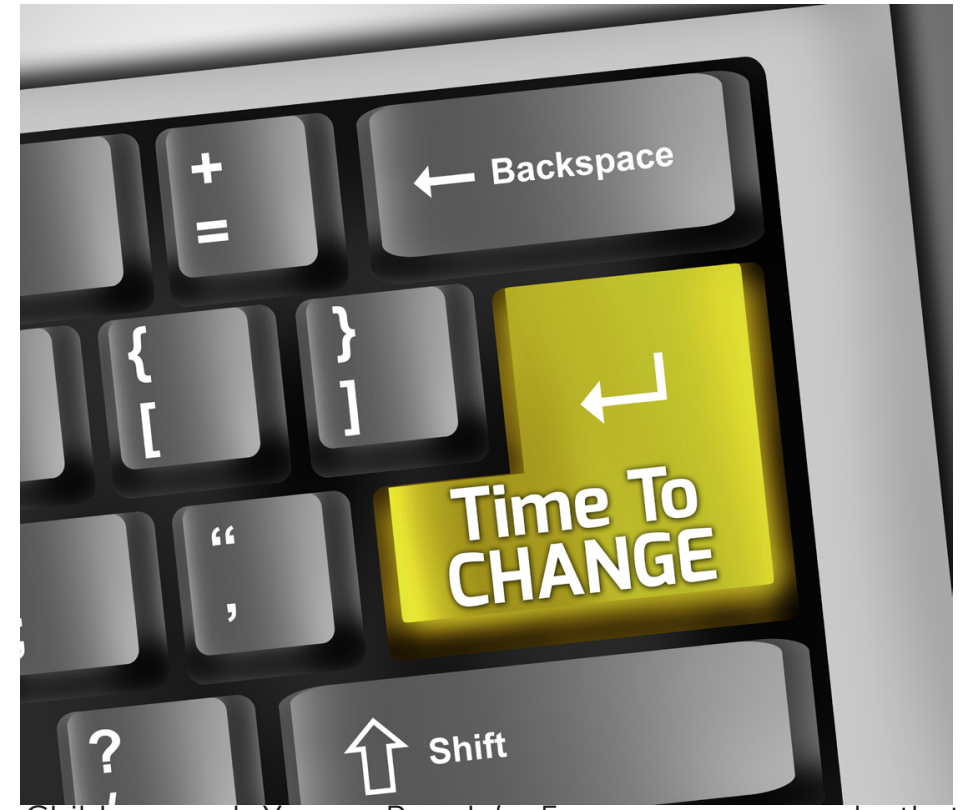

Children and Young People's Forum recommends that all organisations should adopt a life-course approach in configuring services in order to coherently address different stages in life and the key transitions associated with them, and avoid tackling individual risk factors in isolation [72]. In the context of integrating health and social services, it adds that CCGs, together with their local authority partners, should ensure sufficient clinical expertise and leadership for looked-after children, including a designated doctor and nurse. Local networks and partnerships with providers should be developed to deliver sustainable local acute, surgical, mental health and community children's services and exclude gaps in provision. Health Education England should provide strategic direction for training staff involved in children's services and professional bodies should agree core competencies. Commissioners should identify a senior clinical lead for children and young people.

The Social Care Institute for Excellence concluded that good practice in implementing transition arrangements in mental health services involves collaborative, flexible working between agencies, clear protocols and transparent planning meetings, and should include offering young people a trusted adult who can support them through transition [74]. Service users value continuity in staffing and key worker support, with overlap between youth and adult services. There is strong evidence for coordinated working between professionals and agencies, with signposting from one service to another, and this should be taken into account when commissioning services.

In summary, guidance on transition services consistently recommends a single key worker who can provide continuity between paediatric and adult services. Nurses are mentioned as potential key workers, but there is no indication that this is necessary. Consequently, advice on service structure is generic and formed by general principles of clarity, effective communication and partnership. 
different ages until they have the skills necessary for a move to adult services. Taking into account the importance of emotional factors, it may also be necessary to offer access to a psychological service.

\section{Disclosures}

This article was commissioned as part of the Haemnet Transforming Transition programme, which is funded by a grant from the Burdett Trust for Nursing.

This is an Open Access article distributed under the terms of the Creative Commons Attribution License (http://creativecommons.org/licenses/ by/2.0), which permits unrestricted use, distribution, and reproduction in any medium, provided the original work is properly cited.

\section{References}

1. Srivastava A, Brewer AK, Mauser-Bunschoten EP, et al; Treatment Guidelines Working Group on Behalf of The World Federation Of Hemophilia. Guidelines for the management of hemophilia. Haemophilia 2013 Jan;19(1):e1-47. doi: 10.1111/j.1365-2516.2012.02909.x.

2. Department for Education and Skills, Department of Health. Transition. Getting it right for young people. March 2006. (http://webarchive.nationalarchives.gov.uk/20130107105354/http://www.dh.gov.uk/prod_consum_ $\mathrm{dh} /$ groups/dh_digitalassets/@adh/@en/documents/digitalasset/dh_4132149. pdf; accessed 15 September 2015).

3. Department of Health. Core document, National Service Framework for Children, Young People and Maternity Services. October 2004. (https:// www.gov.uk/government/uploads/system/uploads/attachment_data/ file/199952/National_Service_Framework_for_Children_Young_People_ and_Maternity_Services_-_Core_Standards.pdf; accessed 15 September 2015).

4. Care Quality Commission. From the pond into the sea. Children's transition to adult health services. June 2014. (https://www.cqc.org.uk/sites/ default/files/CQC_Transition\%20Report.pdf; accessed 15 September 2015). 5. Beresford B, Cavet J. Transitions to adult services by disabled young people leaving out of authority residential schools. York: Social Policy Research Unit, University of York, 2009. (http://www.york.ac.uk/inst/spru/ pubs/pdf/resident.pdf; accessed 15 September 2015).

6. Clarke S, Sloper P, Moran N et al. Multi-agency transition services: greater collaboration needed to meet the priorities of young disabled people with complex needs as they move into adulthood. J Integrated Care 2011:19:30-40.

7. Singh SP, Paul M, Ford T et al. Process, outcome and experience of transition from child to adult mental healthcare: multiperspective study. $\mathrm{Br}$ J Psychiatry 2010;197:305-12.

8. Hovish K, Weaver T, Islam Z et al. Transition experiences of mental health service users, parents, and professionals in the United Kingdom: a qualitative study. Psychiatric Rehab J 2012;35:251-7.

9. Gordon R. Diabetes transition: Assessment of current best practice and development of a future work programme to improve transition processes for young people. NHS Diabetes, August 2012. (https://www.diabetes. org.uk/Documents/nhs-diabetes/paediatrics/diabetes-transition-report.pdf; accessed 15 September 2015).

10. National Institute for Health and Care Excellence. Transition from children's to adult services for young people using health or social care services. Guideline scope. August 2014. (www.nice.org.uk/guidance/ gid-scwave0714/resources/transition-from-childrens-to-adult-services-final-scope3; accessed 15 September 2015).

11. Department for Children, Schools and Families, Department of Health. Transition: moving on well. A good practice guide for health professionals and their partners on transition planning for young people with complex health needs or a disability. February 2008. (http://www.bacdis.org.uk/ policy/documents/transition_moving-on-well.pdf; accessed 15 September 2015).

12. Royal College of Nursing. Lost in transition. Moving young people between child and adult health services. 2013. (https://www.ren.org. uk/__data/assets/pdf_file/0010/157879/003227_WEB.pdf; accessed 15 September 2015).

13. National Institute for Health and Care Excellence. The epilepsies in children and young people. NICE quality standard QS27. February 2013. (https://www.nice.org.uk/guidance/qs27; accessed 15 September 2015). 14. National Institute for Health and Care Excellence. Attention deficit hyperactivity disorder. NICE quality standard QS39. July 2013. (https://www. nice.org.uk/guidance/qs39; accessed 15 September 2015).

15. NHS England. Proposed congenital heart disease standards and service specifications: a consultation. 15 September 2014 to 8 December 2014. Reference Pack. September 2014. (https://www.engage.england.nhs. uk/consultation/congenital-heart-disease-standards/user_uploads/reference-pack.pdf; accessed 15 September 2015).

16. NHS Improving Quality. Parents' round table discussion. What will the parents say? February 2014. (www.nhsiq.nhs.uk/download.ashx? mid=9190\&nid=9192; accessed 15 September 2015).

17. Beresford B. Making a difference for young adult patients. Practice prompts: key messages from research. Together for Short Lives, August 2013. (http://www.togetherforshortlives.org.uk/assets/0000/4954/TfSL_ Making_a_difference_for_young_adult_patients_A5_Cards_x_12__FlNAL_.pdf; accessed 15 September 2015).

18. Department for Education, Department of Health. 0 to 25 SEND code of practice: a guide for health professionals. September 2014

19. National Network of Parent Carer Forums. What good integrated care looks like in transition. NNPCF Steering Group, August 2013. (https://docs google. com/viewer?a=v\&pid=sites\&srcid=ZGVmYXVsdGRvbWFpbnxubnBjZnRIbXB8Z3g6MzZiMTM4MzFkZGExZmRhMw; accessed 15 September 2015)

20. American Heart Association Congenital Heart Defects Committee of the Council on Cardiovascular Disease in the Young, Council on Cardiovascular Nursing, Council on Clinical Cardiology, and Council on Peripheral Vascular Disease. Best practices in managing transition to adulthood for adolescents with congenital heart disease: the transition process and medical and psychosocial issues: a scientific statement from the American Heart Association. Circulation 2011:123:1454-85.

21. McLaughlin SE, Diener-West M, Indurkhya A et al. Improving transition from pediatric to adult cystic fibrosis care: lessons from a national survey of current practices. Pediatrics 2008;121:e1160-6.

22. Begley T. Transition to adult care for young people with long-term conditions. Br J Nurs 2013;22:506, 508-11.

23. Gravelle A, Davidson G, Chilvers M. Cystic fibrosis adolescent transition care in Canada: a snapshot of current practice. Paediatr Child Health 2012;17:553-6

24. Tuchman L, Schwartz M. Health outcomes associated with transition from pediatric to adult cystic fibrosis care. Pediatrics 2013;132:847-53. 25. Raymond JK, Duke DC, Shimomaeda L, on behalf of the Harold Schnitzer Diabetes Health Center Transition Committee MA. Looking forward to transition: perspectives on transition from pediatric to adult diabetes care. Diabetes Manag (Lond) 2013;3(4):10.2217/dmt.13.27. doi:10.2217/ dmt.13.27.

26. Hilliard ME, Perlus JG, Clark LM et al. Perspectives from before and after the pediatric to adult care transition: a mixed-methods study in type 1 diabetes. Diabetes Care 2014;37:346-54.

27. Garvey KC, Beste MG, Luff D et al. Experiences of health care transition voiced by young adults with type 1 diabetes: a qualitative study. Adolesc Health Med Ther 2014;5:191-8.

28. Garvey KC, Wolpert HA, Laffel LM et al. Health care transition in young adults with type 1 diabetes: barriers to timely establishment of adult diabetes care. Endocr Pract 2013;19:946-52.

29. Lotstein DS, Seid M, Klingensmith G et al. Transition from pediatric to adult care for youth diagnosed with type 1 diabetes in adolescence. Pediatrics 2013;131:e1062-70.

30. de Beaufort C, Jarosz-Chobot P, Frank M, de Bart J, Deja G. Transition from pediatric to adult diabetes care: smooth or slippery? Pediatr Diabetes 2010;11:24-7.

31. Singh SP, Paul M, Ford T et al. Transitions of care from Child and Adolescent Mental Health Services to Adult Mental Health Services (TRACK 
Study): a study of protocols in Greater London. BMC Health Serv Res 2008:8:135. doi: 10.1186/1472-6963-8-135.

32. Iyer A, Appleton R. Transitional services for adolescents with epilepsy in the UK: a survey. Seizure 2013:22:433-7.

33. Singh SP, Paul M, Ford T et al. Process, outcome and experience of transition from child to adult mental healthcare: multiperspective study. $\mathrm{Br}$ J Psychiatry 2010;197:305-12.

34. Gibson F, Aldiss S, Cass H et al. Benchmarks for transition from child to adult health services. London South Bank University, Orchid and Great Ormond Street Children's Hospital, 2014 (http://www.transitionstudy. co.uk/assets/benchmarksfortransitionfromchildtoadulthealthservicesfinal. pdf; accessed 15 September 2015).

35. Together For Short Lives. Transition - A guide for clinical commissioning groups. April 2015. (http://www.togetherforshortlives.org.uk/professionals/resources/7959_transition___a_guide_for_clinical_commissioning_groups; accessed 15 September 2015).

36. NHS England. CCG Outcomes Indicator Set 2014/15 - at a glance December 2013 (www.england.nhs.uk/wp-content/uploads/2013/12/ccgois-1415-at-a-glance.pdf; accessed 15 September 2015)

37. Department of Health. You're welcome. Quality criteria for young people friendly health services. London. April 2011. (https://www.gov. uk/government/uploads/system/uploads/attachment_data/file/216350/ dh_127632.pdf; accessed 15 September 2015).

38. Paul M, Street C, Wheeler $N$ et al. Transition to adult services for young people with mental health needs: a systematic review. Clin Child Psychol Psychiatry 2015;20:436-57.

39. Geerts E, van de Wiel H, Tamminga R. A pilot study on the effects of the transition of paediatric to adult health care in patients with haemophilia and in their parents: patient and parent worries, parental illness-related distress and health-related quality of life. Haemophilia 2008;14:1007-13. 40. Steinkamp G, Ullrich G, Müller C et al. Transition of adult patients with cystic fibrosis from paediatric to adult care - the patients' perspective before and after start-up of an adult clinic. Eur J Med Res 2001;6:85-92. 41. Craig SL, Towns S, Bibby H. Moving on from paediatric to adult health care: an initial evaluation of a transition program for young people with cystic fibrosis. Int J Adolesc Med Health 2007;19:333-43.

42. Rollo A, Salardi S, Ciavarella A et al. Transition from pediatric to adult care. Eight years after the transition from pediatric to adult diabetes care: metabolic control, complications and associated diseases. J Endocrinol Invest 2014;37:653-9.

43. Markowitz JT, Laffel LM. Transitions in care: support group for young adults with type 1 diabetes. Diabet Med 2012 Apr;29(4):522-5.

44. Holmes-Walker DJ, Llewellyn AC, Farrell K. A transition care programme which improves diabetes control and reduces hospital admission rates in young adults with type 1 diabetes aged 15-25 years. Diabet Med 2007:24:764-9.

45. Cadario F, Prodam F, Bellone S et al. Transition process of patients with type 1 diabetes (T1DM) from paediatric to the adult health care service: a hospital-based approach. Clin Endocrinol (Oxf) 2009;71:346-50. 46. Dolan L, Anderson A, Bell RA et al. Transition from pediatric to adult care for youth diagnosed with type 1 diabetes in adolescence. Pediatrics 2013;131:e1062-70.

47. Sheehan AM, While AE, Coyne I. The experiences and impact of transition from child to adult healthcare services for young people with type 1 diabetes: a systematic review. Diabet Med 2014 Nov 18. doi: 10.1111/ dme.12639.

48. Mackie AS, Islam S, Magill-Evans J et al. Healthcare transition for youth with heart disease: a clinical trial. Heart 2014;100:1113-8.

49. Huang JS, Terrones L, Tompane T et al. Preparing adolescents with chronic disease for transition to adult care: a technology program. Pediatrics 2014;133: e1639-46.

50. Steinbeck KS, Shrewsbury VA, Harvey V et al. A pilot randomized controlled trial of a post-discharge program to support emerging adults with type 1 diabetes mellitus transition from pediatric to adult care. Pediatr Diabetes 2014 Nov 11. doi: 10.1111/pedi.12229.

51. Haber MG, Karpur A, Deschenes $N$ et al. Predicting improvement of transitioning young people in the partnerships for youth transition initiative: findings from a multisite demonstration. J Behav Health Serv Res 2008; $35: 488-513$
52. Gravelle AM, Paone M, Davidson AG et al. Evaluation of a multidimensional cystic fibrosis transition program: a quality improvement initiative. $J$ Pediatr Nurs 2015:30:236-43.

53. Chaudhry SR, Keaton M, Nasr SZ. Evaluation of a cystic fibrosis transition program from pediatric to adult care. Pediatr Pulmonol 2013;48:65865.

54. Gilmer TP, Ojeda VD, Fawley-King K, Larson B, Garcia P. Change in mental health service use after offering youth-specific versus adult programs to transition-age youths. Psychiatr Serv 2012;63:592-6.

55. Styron T, O'Connell M, Smalley W et al. Troubled youth in transition: an evaluation of Connecticut's special services for individuals aging out of adolescent mental health programs. Child Youth Serv Rev 2006;28:1088101

56. Johnston P, Bell PM, Tennet $\mathrm{H}$ et al. Audit of young people with type 1 diabetes transferring from paediatric to adult diabetic services. J Diabet Nurs 2008;12:106-8.

57. Logan J, Peralta E, Brown K. Smoothing the transition from paediatric to adult services in type 1 diabetes. Practical Diabetes International 2006;23:106-108.

58. Vidal M, Jansa M Anguita C et al. Impact of a special therapeutic education programme in patients transferred from a paediatric to an adult diabetes unit. Eur Diabet Nurs 2004;1:23-7.

59. Harden PN, Walsh G, Bandler N et al. Bridging the gap: an integrated paediatric to adult clinical service for young adults with kidney failure. $B M J$ 2012:344:e3718 doi: 10.1136/bmj.e3718

60. Prestidge C1, Romann A, Djurdjev $\bigcirc$ et al. Utility and cost of a renal transplant transition clinic. Pediatr Nephrol 2012;27:295-302.

61. Kuchenbuch M, Chemaly N, Chiron C et al. Transition and transfer from pediatric to adult health care in epilepsy: a families' survey on Dravet syndrome. Epilepsy Behav 2013;29:161-5.

62. Felsenstein S1, Reiff AO, Ramanathan A. Transition of care and health-related outcomes in pediatric onset systemic lupus erythematosus. Arthritis Care Res 2015 May 4. doi: 10.1002/acr.22611.

63. Summers SJ, Elliott S, McAdams S et al. Urologic problems in spina bifida patients transitioning to adult care. Urology 2014:84:440-4 64. Wiener LS, Zobel M, Battles $\mathrm{H}$ et al. Transition from a pediatric HIV intramural clinical research program to adolescent and adult community-based care services: assessing transition readiness. Soc Work Health Care 2007:46:1-19

65. Andemariam B, Owarish-Gross J, Grady J et al. Identification of risk factors for an unsuccessful transition from pediatric to adult sickle cell disease care. Pediatr Blood Cancer 2014;61:697-701.

66. Freyer DR, Kibrick-Lazear R. In sickness and in health: transition of cancer-related care for older adolescents and young adults. Cancer 2006:107(7 Suppl):1702-9.

67. Schwartz LA, Daniel LC, Brumley LD et al. Measures of readiness to transition to adult health care for youth with chronic physical health conditions: a systematic review and recommendations for measurement testing and development. J Pediatr Psychol 2014:39:588-601.

68. Department of Health, NHS Careers. NHS Career Planner for Nurses. Lead nurse. (http://nursingcareers.nhsemployers.org/browse-segments/ first-contact-access-and-urgent-care/level-8-management/lead-nurse. aspx; accessed 17th August 2015).

69. Kelly $D$. Theory to reality: the role of the transition nurse coordinator. Br J Nurs 2014;23:888, 890, 892-4.

70. Jurasek L, Ray L, Quigley D. Development and implementation of an adolescent epilepsy transition clinic. J Neurosci Nurs 2010;42:181-9. 71. Joint Commissioning Panel for Mental Health. Guidance for commissioners of mental health services for young people making the transition from child and adolescent to adult services. Volume two: Practical mental health commissioning. March 2012. (https://www.rcpsych.ac.uk/pdf/JCPMH\%20CAMHS\%20transitions\%20\%28March\%202012\%29.pdf; accessed 15 September 2015)

72. Children and Young People's Health Outcomes Strategy. Report of the Children and Young People's Health Outcomes Forum. July 2012. (https:// www.gov.uk/government/uploads/system/uploads/attachment_data/ file/216852/CYP-report.pdf; accessed 15 September 2015).

73. Brodie I, Goldman R, Clapton J. Mental health service transitions for young people. SCIE Research briefing 37. Social Care Institute for Clinical 
Excellence, May 2011. (http://www.scie.org.uk/publications/briefings/briefing37/; accessed 15 September 2015).

74. Social Care Institute for Excellence. Mental health service transitions for young people. SCIE Guide 44. November 2011. (www.scie.org.uk/publications/guides/guide44/files/guide44.pdf; accessed 19th August 2015). 75. Heery E, Sheehan AM, While AE et al. Experiences and outcomes of transition from pediatric to adult health care services for young people with congenital heart disease: a systematic review. Congenit Heart Dis 2015 Feb 9. doi:10.1111/chd.12251.

76. Gray WN, Resmini AR, Baker KD et al. Concerns, barriers, and recommendations to improve transition from pediatric to adult IBD care: perspectives of patients, parents, and health professionals. Inflamm Bowel Dis 2015;21:1641-51.

77. Plevinsky JM, Gumidyala AP, Fishman LN. Transition experience of young adults with inflammatory bowel diseases (IBD): a mixed methods study. Child Care Health Dev 2015:41:755-61.

78. Department of Health. Self care - a real choice. 2005. (http://webarchive.national archives.gov.uk/20130107105354/http://www.dh.gov.uk/ prod_consum_dh/groups/dh_digitalassets/@adh/@en/documents/digitalasset/dh_4101702.pdf; accessed 19th August 2015)

79. Sattoe JN, Bal MI, Roelofs PD et al. Self-management interventions for young people with chronic conditions: a systematic overview. Patient Educ Couns 2015:98:704-15.

80. Department of Health. Your health, your way. A guide to long term conditions and self care. Information for healthcare professionals. April 2009. (http://webarchive.nationalarchives.gov.uk/20130107105354/http:// www.dh.gov.uk/prod_consum_dh/groups/dh_digitalassets/documents/ digitalasset/dh_097586.pdf; accessed 19th August 2015)

81. American Academy of Pediatrics; American Academy of Family Physicians; American College of Physicians; Transitions Clinical Report Authoring Group, Cooley WC, Sagerman PJ. Supporting the health care transition from adolescence to adulthood in the medical home. Pediatrics 2011:128:182-200.

82. Lindvall K, Colstrup L, Wollter IM et al. Compliance with treatment and understanding of own disease in patients with severe and moderate haemophilia. Haemophilia 2006;12:47-51.

83. Gray WN, Holbrook E, Morgan PJ et al. Transition readiness skills acquisition in adolescents and young adults with inflammatory bowel disease: findings from integrating assessment into clinical practice. Inflamm Bowel Dis 2015:21:1125-31.

84. Beal SJ, Nye A, Marraccini A et al. Evaluation of readiness to transfer to adult healthcare: what about the well adolescent? Healthc (Amst) 2014:2:225-31.

85. Okumura MJ, Ong T, Dawson D et al. Improving transition from paediatric to adult cystic fibrosis care: programme implementation and evaluation. BMJ Qual Saf 2014;23 Suppl 1:i64-i72.

86. Asp A, Bratt EL, Bramhagen AC. Transfer to adult care - experiences of young adults with congenital heart disease. J Pediatr Nurs 2015; July 18 doi: 10.1016/j.pedn.2015.05.025

87. Gibson-Scipio W, Gourdin D et al. Asthma self-management goals, beliefs and behaviors of urban African American adolescents prior to transitioning to adult health care. J Pediatr Nurs 2015 Jul 10. pii: S08825963(15)00212-2. doi: 10.1016/j.pedn.2015.06.012.

88. Gorter JW, Stewart D, Cohen E et al. Are two youth-focused interventions sufficient to empower youth with chronic health conditions in their transition to adult healthcare: a mixed-methods longitudinal prospective cohort study. BMJ Open 2015;5:e007553. doi: 10.1136/bmjopen-2014-007553.

89. Ferris ME, Cuttance JR, Javalkar K et al. Self-management and transi- tion among adolescents/young adults with chronic or end-stage kidney disease. Blood Purif 2015;39:99-104.

90. Annunziato RA, Arrato N, Rubes M, Arnon R. The importance of mental health monitoring during transfer to adult care settings as examined among paediatric transplant recipients. J Paediatr Child Health 2015:51:220-2

91. Mitchell F. Facilitators and barriers to informed choice in self-directed support for young people with disability in transition. Health Soc Care Community 2015;23:190-9.

92. van Staa A, Sattoe JN. Young adults' experiences and satisfaction with the transfer of care. J Adolesc Health 2014;55:796-803.

93. Molter BL, Abrahamson K. Self-efficacy, transition, and patient outcomes in the sickle cell disease population. Pain Manag Nurs 2015;16:41824.

94. Javalkar K, Fenton N, Cohen S et al. Socioecologic factors as predictors of readiness for self-management and transition, medication adherence, and health care utilization among adolescents and young adults with chronic kidney disease. Prev Chronic Dis 2014 Jul 10;11:E117. doi: 10.5888/ pcd11.140072.

95. Fernandes SM, O'Sullivan-Oliveira J, Landzberg MJ et al. Transition and transfer of adolescents and young adults with pediatric onset chronic disease: the patient and parent perspective. J Pediatr Rehabil Med 2014;7:4351.

96. Hanna KM, Weaver MT, Stump TE et al. Readiness for living independently among emerging adults with type 1 diabetes. Diabetes Educ 2013:39:92-9

97. Gravelle AM, Paone M, Davidson AG et al. Evaluation of a multidimensional cystic fibrosis transition program: a quality improvement initiative. J Pediatr Nurs 2015;30:236-43.52.

98. Styron T, O'Connell M, Smalley W et al. Troubled youth in transition: An evaluation of Connecticut's special services for individuals aging out of adolescent mental health programs. Children and Youth Services Review 2006;28:1088-101.

99. Crowley R, Wolfe I, Lock K, McKee M. Improving the transition between paediatric and adult healthcare: a systematic review. Arch Dis Child 2011 Jun;96(6):548-53.

C, An I. Pharmacology aspects during transition and at transfer in patients with epilepsy. Epilepsia 2014 Aug:55 Suppl 3:8-11.

101. Bindels-de Heus KGCB, van Staa A, van Vliet I, Ewals FVPM, Hilberink SR. Transferring young people with profound intellectual and multiple disabilities from pediatric to adult medical care: parents' experiences and recommendations. Intellect Dev Disabil 2013 Jun;51(3):176-89.

102. Reid GJ, Irvine MJ, McCrindle BW, Sananes R, Ritvo PG, Siu SC, Webb $\mathrm{GD}$. Prevalence and correlates of successful transfer from pediatric to adult health care among a cohort of young adults with complex congenital heart defects.

Pediatrics 2004 Mar:113(3 Pt 1):e197-205.

103. Duguépéroux I, Tamalet A, Sermet-Gaudelus I, Le Bourgeois M, Gérardin M, Desmazes-Dufeu N, Hubert D. Clinical changes of patients with cystic fibrosis during transition from pediatric to adult care. J Adolesc Health 2008 Nov;43(5):459-65 
Table A. Studies reporting client-focused or clinical outcomes

\begin{tabular}{|c|c|c|c|c|}
\hline $\begin{array}{l}\text { Study } \\
\text { Studies evaluating } \\
\text { person-centred } \\
\text { outcomes from a } \\
\text { transition service }\end{array}$ & Client group & Design & Measure & Outcome \\
\hline Paul M et al [38] & $\begin{array}{l}\text { CAMHS-AMSH } \\
\text { transitional care, } \\
\text { service users and } \\
\text { staff }\end{array}$ & $\begin{array}{l}\text { Systematic review } \\
\text { 'This systematic } \\
\text { review, which we } \\
\text { believe to be the } \\
\text { first in the mental } \\
\text { health service } \\
\text { transitions literature, } \\
\text { clearly shows a } \\
\text { lack of adequately } \\
\text { powered studies, } \\
\text { RCTs or case- } \\
\text { controlled studies } \\
\text { that evaluate the } \\
\text { effectiveness of } \\
\text { different models of } \\
\text { transitional mental } \\
\text { health care for } \\
\text { young people.' }\end{array}$ & $\begin{array}{l}\text { Are different models } \\
\text { of transitional mental } \\
\text { health care for young } \\
\text { people effective in } \\
\text { achieving transfer of } \\
\text { care and improving } \\
\text { the quality of } \\
\text { transitional care? } \\
\text { What do young } \\
\text { people and their } \\
\text { parents/carers } \\
\text { (hereafter called } \\
\text { parents) report about } \\
\text { their experience of } \\
\text { transition? } \\
\text { What do professionals } \\
\text { working within mental } \\
\text { health services report } \\
\text { on the adequacy } \\
\text { of provision of } \\
\text { facilitators of and } \\
\text { barriers to effective } \\
\text { CAMHS-AMHS } \\
\text { transition? }\end{array}$ & $\begin{array}{l}\text { This review cites three studies: } \\
\text { High-risk young adults ( } \mathrm{n}=60 \text { ) with moderate/ } \\
\text { severe mental illness. Treatment planning variables } \\
\text { 囚 strengths-focused treatment planning (SFTP) } \\
\text { and community-focused treatment planning } \\
\text { (CFTP) } \text { s significantly correlated with positive } \\
\text { outcomes: fewer symptoms, less loneliness, fewer } \\
\text { mental health problems, higher functioning and } \\
\text { greater satisfaction with services. SFTP contributed } \\
\text { significantly to greater quality of life and CFTP to } \\
\text { fewer arrests. } \\
\text { 193/562 young people aged } 14-21 \text { years, enrolled } \\
\text { in five Partnerships for Youth Transition (PYT) } \\
\text { services for adolescents with serious mental } \\
\text { health conditions. Programme tenure was } \\
\text { significantly associated with increased educational } \\
\text { advancement, employment and productivity and } \\
\text { decreased criminal justice involvement, mental } \\
\text { health symptom interference and substance abuse } \\
\text { interference. The over-19s did better than younger } \\
\text { people. Those with mood/learning disorders } \\
\text { had better outcomes than those with disruptive } \\
\text { behaviour disorders. } \\
\text { Outpatient programme within AMHS tailored for } \\
\text { transition-age young people (18-24 year olds) } \\
\text { (n = 931) vs standard outpatient AMHS (1574). } \\
\text { Mean outpatient visits were } 12 \% \text { greater within the } \\
\text { tailored service. }\end{array}$ \\
\hline Geerts E et al [39] & $\begin{array}{l}\text { Young people } \\
\text { with haemophilia } \\
\text { and their parents, } \\
\text { paediatric } \\
\text { haemophilia } \\
\text { centres, The } \\
\text { Netherlands }\end{array}$ & $\begin{array}{l}\text { Pilot study } \\
\text { comparing pre- and } \\
\text { post-transition } \\
\text { patients }(n=17) \text { and } \\
\text { their parents }(n=39)\end{array}$ & $\begin{array}{l}\text { 5-point Likert scale } \\
\text { for worry } \\
\text { Haemo-QoL-A for } \\
\text { patients, adults and } \\
\text { parents for health- } \\
\text { related quality of life }\end{array}$ & $\begin{array}{l}\text { No difference in health-related quality of life } \\
\text { between pre- and post-transition patients. } \\
\text { Fathers of post-transition patients rated their son's } \\
\text { health-related quality of life worse than fathers } \\
\text { of pre-transition patients and had higher levels of } \\
\text { illness-related stress. }\end{array}$ \\
\hline $\begin{array}{l}\text { Steinkamp G et al [ } 40 \\
\text { abstract only] }\end{array}$ & $\begin{array}{l}\text { People with cystic } \\
\text { fibrosis aged } 18 \otimes 33 \\
(n=44)\end{array}$ & $\begin{array}{l}\text { Questionnaire } \\
\text { survey } 9 \text { months } \\
\text { before transition, } \\
\text { with follow-up 15 } \\
\text { months afterwards }\end{array}$ & $\begin{array}{l}\text { Patient rating of } \\
\text { quality of care in adult } \\
\text { and paediatric centres }\end{array}$ & Adult services rated better than paediatric services. \\
\hline Craig SL et al [41] & $\begin{array}{l}\text { Pre-transition } \\
\text { adolescents and } \\
\text { their parents and } \\
\text { a 'post-transition' } \\
\text { group who had } \\
\text { moved on over a six } \\
\text { year period ( } n=137 \text { ) }\end{array}$ & Questionnaire & $\begin{array}{l}\text { Satisfaction, CF- } \\
\text { related quality of life, } \\
\text { lung function, BMI }\end{array}$ & $\begin{array}{l}\text { Of the post-transition group, } 55 \% \text { rated the overall } \\
\text { transition as good/excellent, } 28 \% \text { as fair and } 17 \% \\
\text { as poor/very poor. } 76 \% \text { felt that they received } \\
\text { the information they needed and the transition } \\
\text { process met their needs. } 62 \% \text { felt supported during } \\
\text { transition and } 62 \% \text { felt prepared for transition. } \\
\text { No relationship between number of transition } \\
\text { steps completed and quality of life, lung function } \\
\text { or BMI. }\end{array}$ \\
\hline Rollo A et al [42] & $\begin{array}{l}\text { Adults who had } \\
\text { transferred to adult } \\
\text { diabetes services } \\
\text { via a transition } \\
\text { programme }(n=69)\end{array}$ & $\begin{array}{l}\text { Longitudinal } \\
\text { non-comparative } \\
\text { study with } 8 \text { years' } \\
\text { follow-up }\end{array}$ & $\begin{array}{l}\text { Metabolic } \\
\text { control (HbA1c), } \\
\text { complications }\end{array}$ & $\begin{array}{l}\text { No change in } \mathrm{HbA} 1 \mathrm{c} \text { before, during or after } \\
\text { transition. }\end{array}$ \\
\hline
\end{tabular}




\begin{tabular}{|c|c|c|c|c|}
\hline Markowitz JT et al [43] & $\begin{array}{l}\text { Support group for } \\
\text { young adults with } \\
\text { type } 1 \text { diabetes } \\
(n=15)\end{array}$ & $\begin{array}{l}\text { Longitudinal } \\
\text { study of group } \\
\text { transferring to adult } \\
\text { service }\end{array}$ & $\begin{array}{l}\text { Diabetes burden, } \\
\text { self-care, glycaemic } \\
\text { control, patient } \\
\text { preferences }\end{array}$ & $\begin{array}{l}\text { No significant change in HbAlc. } \\
\text { Significant reduction in burden of diabetes score } \\
\text { and increase in self-care score. } \\
\text { Participants preferred care providers awho were } \\
\text { knowledgeable, supportive and responsiave, and } \\
\text { worked within a multidisciplinary team. They } \\
\text { reported a need for communication with providers } \\
\text { to improve; those who had changed treatment } \\
\text { teams reported discomfort with their providers } \\
\text { due to inadequate knowledge and insufficient } \\
\text { interaction time. }\end{array}$ \\
\hline $\begin{array}{l}\text { Holmes-Walker DJ et } \\
\text { al [44] }\end{array}$ & $\begin{array}{l}15-25 \text { year olds } \\
\text { with type } 1 \text { diabetes } \\
\text { referred to a young } \\
\text { adults' clinic }(n=191)\end{array}$ & $\begin{array}{l}\text { Cohort study } \\
\text { comparing pre- and } \\
\text { post-intervention; } \\
3.5 \text { years' follow-up }\end{array}$ & Glycaemic control & $\begin{array}{l}\text { HbA1c lowered after } 5 \text { visits than at referral; } \\
\text { more patients had good glycaemic control, but } \\
\text { difference not statistically significant. } \\
\text { Admissions for DKA and length of stay both } \\
\text { significantly reduced after intervention. }\end{array}$ \\
\hline Cadario F et al [45] & $\begin{array}{l}\text { Adolescents and } \\
\text { young adults } \\
\text { with type } 1 \\
\text { diabetes }(n=62) \text {; } \\
32 \text { transferred } \\
\text { in unstructured } \\
\text { way, } 30 \text { through } \\
\text { a transition } \\
\text { programme }\end{array}$ & $\begin{array}{l}\text { Cross-sectional } \\
\text { survey by } \\
\text { questionnaire } \\
\text { comparing } \\
\text { transition vs. } \\
\text { unstructured } \\
\text { transfer }\end{array}$ & $\begin{array}{l}\text { Medical treatment, } \\
\text { patients' feelings } \\
\text { about service }\end{array}$ & $\begin{array}{l}\text { Initial HbA1c lower after transfer in transition } \\
\text { group, than unstructured. At one year, HbA1c } \\
\text { lower after transition than unstructured. HbA1c } \\
\text { similar after } 3 \text { years. } \\
\text { Patient opinion about transition programme } 100 \% \\
\text { positive vs. } 30 \% \text { for unstructured. }\end{array}$ \\
\hline Garvey KC et al [46] & $\begin{array}{l}\text { Young adults with } \\
\text { type } 1 \text { diabetes at a } \\
\text { single US centre }\end{array}$ & $\begin{array}{l}\text { Cross-sectional, } \\
\text { survey }\end{array}$ & Metabolic control & $\begin{array}{l}\text { 'No independent association of transition } \\
\text { preparation with post-transition } A 1 C^{\prime} \text {. }\end{array}$ \\
\hline Sheehan AM et al [47] & $\begin{array}{l}43 \text { studies } \\
\text { evaluating the } \\
\text { impact and } \\
\text { experiences of } \\
\text { transition; various } \\
\text { models included }\end{array}$ & Systematic review & $\begin{array}{l}\text { Glycaemic control, } \\
\text { complications, insulin } \\
\text { dose }\end{array}$ & $\begin{array}{l}6 / 10 \text { studies reported lower HbA1c after transition } \\
\text { programme, } 4 / 10 \text { no change, but lack of controls } \\
\text { and comparators. } \\
\text { Other outcomes mixed. } \\
\text { Some patients considered their experiences } \\
\text { to have been positive; others were negative or } \\
\text { described difficulties accessing care. Satisfaction } \\
\text { with the process ranged from } 57 \% \text { to } 94 \% \text { and } \\
\text { dissatisfaction from } 3 \% \text { to } 20 \% \text {. Sense of loss and } \\
\text { sometimes abandonment when relationships with } \\
\text { paediatric staff were severed. }\end{array}$ \\
\hline Mackie et al [48] & $\begin{array}{l}15-17 \text { year-olds } \\
\text { with moderate or } \\
\text { complex congenital } \\
\text { heart disease (CHD) } \\
\text { or cardiomyopathy } \\
(n=58)\end{array}$ & $\begin{array}{l}\text { Prospective } \\
\text { comparison of } \\
\text { usual care with a } \\
\text { one-hour nurse-led } \\
\text { personal teaching } \\
\text { session about their } \\
\text { heart }\end{array}$ & $\begin{array}{l}\text { Change in Transition } \\
\text { Readiness Assessment } \\
\text { Questionnaire (TRAQ) } \\
\text { score at } 6 \text { months; } \\
\text { cardiac knowledge } \\
\text { (MyHeart score, range } \\
0-100 \text { ) }\end{array}$ & $\begin{array}{l}\text { Nurse-led intervention improved knowledge. } \\
\text { Mean self-management TRAQ score after } \\
\text { intervention was } 3.59 \text { vs. } 3.16 \text { for controls. } \\
\text { Mean self-advocacy TRAQ score was } 4.38 \text { vs. } 4.01 \\
\text { NS). } \\
\text { Mean MyHeart score was } 75 \% \text { vs. } 61 \% \text {. }\end{array}$ \\
\hline Huang JS et al [49] & $\begin{array}{l}\text { Adolescents with } \\
\text { chronic disease, } \\
\text { aged } 12-20(n=81)\end{array}$ & $\begin{array}{l}\text { Randomised } \\
\text { clinical trial; } 2 \\
\text { months' transition } \\
\text { intervention } \\
\text { (intensive disease } \\
\text { management } \\
\text { and skill-based } \\
\text { intervention) or } \\
\text { usual care, then } 6 \\
\text { months' review }\end{array}$ & $\begin{array}{l}\text { Disease status, global } \\
\text { health status, health } \\
\text { literacy, Transition } \\
\text { Readiness Assessment } \\
\text { Questionnaire, Patient } \\
\text { Activation Measure, } \\
\text { patient-initiated } \\
\text { communications } \\
\text { assessments at } 2 \text { and } \\
8 \text { months }\end{array}$ & $\begin{array}{l}\text { Programme recipients had increased disease } \\
\text { self-management, health-related self-efficacy and } \\
\text { patient-initiated communications with healthcare } \\
\text { team. } \\
\text { Disease status, functional performance, and quality } \\
\text { of life did not significantly differ or change. }\end{array}$ \\
\hline Steinbeck KS et al [50] & $\begin{array}{l}\text { Young people } \\
\text { leaving paediatric } \\
\text { diabetes services } \\
(n=26)\end{array}$ & $\begin{array}{l}\text { Prospective } \\
\text { randomised } \\
\text { trial comparing } \\
\text { a transition } \\
\text { programme with } \\
\text { usual care }\end{array}$ & $\begin{array}{l}\text { Engagement and } \\
\text { retention in the } \\
\text { adult service at } \\
12 \text { months; HbA1c, } \\
\text { diabetes-related } \\
\text { hospitalisations, } \\
\text { microvascular } \\
\text { complication } \\
\text { appearance and } \\
\text { global self-worth }\end{array}$ & $\begin{array}{l}\text { HbA1c higher at baseline and follow-up among } \\
\text { participants of transition programme. } \\
\text { No other differences. }\end{array}$ \\
\hline
\end{tabular}




\begin{tabular}{|c|c|c|c|c|}
\hline Haber MG et al [51] & $\begin{array}{l}\text { Partnerships for } \\
\text { Youth Transition } \\
\text { initiative, a } \\
\text { 4-year, multisite } \\
\text { demonstration } \\
\text { to support five } \\
\text { comprehensive, } \\
\text { community-based } \\
\text { transition support } \\
\text { programmes for } \\
\text { young people in the } \\
\text { US ( } n=193 \text { ) }\end{array}$ & $\begin{array}{l}\text { Retrospective } \\
\text { review of change } \\
\text { in indicators of } \\
\text { improvement }\end{array}$ & $\begin{array}{l}\text { Employment, } \\
\text { educational } \\
\text { advancement, } \\
\text { criminal justice } \\
\text { involvement, mental } \\
\text { health interference, } \\
\text { substance use } \\
\text { interference, } \\
\text { productivity }\end{array}$ & $\begin{array}{l}\text { Progress in all or most of the domains examined in } \\
\text { all five demonstration sites. }\end{array}$ \\
\hline Gravelle AM et al [52] & $\begin{array}{l}\text { Transition care } \\
\text { clinical pathways } \\
\text { for young people } \\
\text { with cystic fibrosis } \\
(n=22)\end{array}$ & $\begin{array}{l}\text { Retrospective } \\
\text { appraisal of imple- } \\
\text { mentation of steps } \\
\text { in pathway }\end{array}$ & $\begin{array}{l}\text { Adherence with pro- } \\
\text { cess (\% of indicators } \\
\text { met by patients) }\end{array}$ & Process validated. \\
\hline Chaudhry SR et al [53] & $\begin{array}{l}\text { Adults attending } \\
\text { cystic fibrosis } \\
\text { centre }(n=91)\end{array}$ & $\begin{array}{l}\text { Cross-sectional: } \\
\text { questionnaire } \\
\text { comparison of } \\
\text { those who had } \\
\text { gone through } \\
\text { transition } \\
\text { programme vs. } \\
\text { those who had not }\end{array}$ & $\begin{array}{l}\text { Questions about satis- } \\
\text { faction, anxiety, health } \\
\text { status, independence }\end{array}$ & $\begin{array}{l}\text { Participants reported higher levels of satisfaction } \\
\text { before transition but not after; higher perceived } \\
\text { health status before and after; no other significant } \\
\text { differences. }\end{array}$ \\
\hline
\end{tabular}

\section{Studies evaluating transfer to adult services without a transition programme, or outcomes other than person-centred}

\begin{tabular}{|c|c|c|c|c|}
\hline Chiron et al, 2014 [100 & $\begin{array}{l}\text { Young people with } \\
\text { drug-resistant } \\
\text { epilepsy syndromes } \\
(n=39)\end{array}$ & $\begin{array}{l}\text { Retrospective } \\
\text { review of transfer } \\
\text { experiences; not } \\
\text { explicitly a transition } \\
\text { process }\end{array}$ & Seizure frequency & $\begin{array}{l}\text { Drug therapy was modified in } 26 \text { patients, with a } \\
\text { reduction in seizure frequency in } 62 \% \text {. } \\
\text { Six previously controlled patients who underwent } \\
\text { planned changes in drug therapy had seizure } \\
\text { relapse. }\end{array}$ \\
\hline $\begin{array}{l}\text { Kuchenbuch et al, } \\
2013 \text { [61] }\end{array}$ & $\begin{array}{l}\text { Survey of parents } \\
\text { of a child ( }>18 \text { ) with } \\
\text { Dravet's syndrome } \\
\text { ( } n=60 \text { families); } 31 \\
\text { patients had experi- } \\
\text { ence of transfer }\end{array}$ & Questionnaire & $\begin{array}{l}\text { Experience of tran- } \\
\text { sition }\end{array}$ & $\begin{array}{l}\text { Of the } 31 \text { patients who underwent transfer, } 13 \\
(40 \%) \text { said the quality of the preparation or the } \\
\text { transition had been inadequate; } 19(60 \%) \text { estimated } \\
\text { that it was appropriate. } \\
\text { Comparing transfer vs. non-transfer patients, } \\
\text { transfer was positively affected by appropriate } \\
\text { transition, a longer duration of follow-up in } \\
\text { the same paediatric setting, good availability of } \\
\text { paediatric staff age }>18 \text {, and good health condition } \\
\text { at transfer. }\end{array}$ \\
\hline $\begin{array}{l}\text { Bindels-de Heus et al, } \\
2013 \text { [101] }\end{array}$ & $\begin{array}{l}\text { Parents of children } \\
\text { with profound } \\
\text { intellectual and } \\
\text { multiple disabilities } \\
\text { ( } n=131 \text { ), of whom } \\
22 \% \text { were in } \\
\text { paediatric care and } \\
22 \% \text { without a care } \\
\text { coordinator }\end{array}$ & $\begin{array}{l}\text { Web-based } \\
\text { questionnaire }\end{array}$ & $\begin{array}{l}\text { Experiences and } \\
\text { satisfaction with } \\
\text { care; feelings about } \\
\text { preparation for } \\
\text { transfer }\end{array}$ & $\begin{array}{l}47 \% \text { with children now in adult care felt their } \\
\text { current coordinating physician was capable of } \\
\text { taking over care from the paediatric department; } \\
33 \% \text { were neutral and } 20 \% \text { disagreed. } \\
\text { Parents who had already left paediatric care had } \\
\text { less appreciation for their current coordinating } \\
\text { physician than for their former paediatrician. } \\
\text { Items on information provision and the emotional } \\
\text { impact of the transfer were scored low. } \\
\text { Two thirds of the parents whose child was still } \\
\text { treated by the paediatrician had not yet been } \\
\text { prepared for transfer to adult care. For } 21 \% \text {, } \\
\text { parents had completed the transfer; preparation } \\
\text { mostly comprised the simple announcement of } \\
\text { the impending transfer. Of the parents without a } \\
\text { coordinating physician, } 28 \% \text { felt there had been no } \\
\text { preparation at all. } \\
60 \% \text { of parents disagreed with the statement 'I } \\
\text { feel/felt ready to leave paediatric care'; } 18 \% \text { agreed } \\
\text { and the rest were neutral. } \\
\text { Of the parents whose child had been transferred } \\
\text { to adult care, } 35 \% \text { agreed with the statement 'I } \\
\text { felt let down by the paediatrician'; } 43 \% \text { disagreed. } \\
\text { Half of parents felt that the transfer should have } \\
\text { been smoother. } 5 \text { parents reported that a joint } \\
\text { consultation between the paediatrician and the } \\
\text { adult physician had occurred. } \\
\text { Most parents who had left paediatric care } \\
\text { confirmed that the paediatrician had transferred } \\
\text { their child's medical history to adult care, but only } \\
13 \text { had received a copy. }\end{array}$ \\
\hline
\end{tabular}




\begin{tabular}{|c|c|c|c|c|}
\hline Reid et al, 2004 [102] & $\begin{array}{l}\text { Patients aged } 19 \\
\bigotimes 21 \text { with complex } \\
\text { congenital heart } \\
\text { defects who should } \\
\text { be seen annually at } \\
\text { a specialised adult } \\
\text { centre }(n=360)\end{array}$ & $\begin{array}{l}\text { Cross-sectional } \\
\text { evaluation of } \\
\text { correlates of } \\
\text { successful transfer } \\
\text { from paediatric to } \\
\text { adult service }\end{array}$ & $\begin{array}{l}\text { Attending at least one } \\
\text { appointment for an } \\
\text { adult service of any } \\
\text { type associated with } \\
\text { cardiac care }\end{array}$ & $\begin{array}{l}\text { Success rate } 47 \% \text {. Correlated with reported } \\
\text { frequency of adolescent cardiac appointments; } \\
\text { beliefs about where and when adult follow-up } \\
\text { should take place; health status; substance use; } \\
\text { dental antibiotic prophylaxis; independence in } \\
\text { attending CHD appointments; CHD-specific health } \\
\text { beliefs about risks of not attending. }\end{array}$ \\
\hline $\begin{array}{l}\text { Okumura et al, } 2014 \\
\text { [85] }\end{array}$ & $\begin{array}{l}\text { Young people with } \\
\text { cystic fibrosis and } \\
\text { their families; staff }\end{array}$ & $\begin{array}{l}\text { Retrospective } \\
\text { evaluation of } \\
\text { process and some } \\
\text { outcomes in first } 18 \\
\text { months of transition } \\
\text { programme }\end{array}$ & $\begin{array}{l}9 \text { young people made } \\
\text { the transition during } \\
\text { the study. Outcomes } \\
\text { defined by process. }\end{array}$ & $\begin{array}{l}4 \text { followed pathway; } 2 \text { admitted; } 3 \text { needed slower } \\
\text { transition due to initial refusal. }\end{array}$ \\
\hline $\begin{array}{l}\text { Tuchman et al, } 2013 \\
\text { [24] }\end{array}$ & $\begin{array}{l}\text { Young people } \\
\text { with cystic fibrosis } \\
(n=1,322) \text {, half of } \\
\text { whom had switched } \\
\text { from paediatric to } \\
\text { adult services }\end{array}$ & $\begin{array}{l}\text { Comparison of lung } \\
\text { function between } \\
\text { those who had or } \\
\text { had not transferred } \\
\text { to adult service } \\
\text { (transition service } \\
\text { not mentioned) }\end{array}$ & $\begin{array}{l}\text { Lung function, BMI, } \\
\text { admissions, infection }\end{array}$ & $\begin{array}{l}\text { No significant changes after } 2 \text { years in } \\
\text { FVC, BMI, annual hospitalisation or events per year } \\
\text { requiring home antibiotic therapy. } \\
\text { Decline in FEV1 was slightly but statistically } \\
\text { significantly slower after transfer. }\end{array}$ \\
\hline $\begin{array}{l}\text { Duguépéroux et al, } \\
2008 \text { [103] }\end{array}$ & $\begin{array}{l}\text { Adults with cystic } \\
\text { fibrosis newly } \\
\text { transferred from } \\
\text { paediatric services } \\
\text { (not a transition } \\
\text { programme) }\end{array}$ & $\begin{array}{l}\text { Comparison of } \\
\text { time of transfer, } \\
1 \text { year earlier } \\
\text { (retrospectively) and } \\
1 \text { year later }\end{array}$ & $\begin{array}{l}\text { Lung function, } \\
\text { antibiotic use, health } \\
\text { status, nutrition }\end{array}$ & $\begin{array}{l}\text { No significant change in lung function measures, } \\
\text { sputum cultures, antibiotic use (though more } \\
\text { treated at home), sports participation. Fewer } \\
\text { studying and more without study or work. } \\
\text { Outpatient visits increased after transfer. }\end{array}$ \\
\hline $\begin{array}{l}\text { Crowley et al, } 2011 \\
\text { [99] }\end{array}$ & $\begin{array}{l}\text { Systematic review } \\
\text { of } 10 \text { studies of } \\
\text { transition for young } \\
\text { people aged } 11- \\
25 \text { with chronic } \\
\text { physical or mental } \\
\text { illness or disability }\end{array}$ & Systematic review & $\begin{array}{l}\text { Health outcomes } \\
\text { appropriate to } \\
\text { condition. } \\
\text { Diabetes } \otimes 8 \text { studies; } \\
\text { cystic fibrosis and } \\
\text { transplant recipients } \\
\otimes 1 \text { study each. Focus } \\
\text { on the transfer event, } \\
\text { not the transition } \\
\text { process. }\end{array}$ & $\begin{array}{l}\text { Lower HbA1c, fewer acute and chronic diabetes } \\
\text { complications, improved self-management } \\
\text { skills, increased screening for complications. No } \\
\text { improvement or conflicting results for attendance } \\
\text { and diabetes-related QoL. }\end{array}$ \\
\hline $\begin{array}{l}\text { Lotstein et al, } 2013 \\
\text { [29] }\end{array}$ & $\begin{array}{l}\text { Adolescents } \\
\text { recently diagnosed } \\
\text { with type } 1 \text { diabetes } \\
\text { ( } n=185) ; 57 \% \text { had } \\
\text { transferred to adult } \\
\text { services by latest } \\
\text { follow-up }\end{array}$ & $\begin{array}{l}\text { Longitudinal study } \\
\text { with follow-up for } \\
\text { up to } 5 \text { years; no } \\
\text { documentation } \\
\text { of participating } \\
\text { in transition } \\
\text { programmes }\end{array}$ & $\begin{array}{l}\text { Glycaemic control } \\
\text { (HbA1c) }\end{array}$ & $\begin{array}{l}\text { Mean } \mathrm{HbA1c} 7.5 \% \text { at baseline and } 9.2 \% \text { at follow- } \\
\text { up. } 11 \% \text { had } \mathrm{HbA1c} \geq 9 \% \text { at baseline compared with } \\
45 \% \text { at follow-up. }\end{array}$ \\
\hline
\end{tabular}

Table B. Studies reporting change in health outcomes after transition

\begin{tabular}{|c|c|c|c|c|}
\hline Study & Client group & Design & Measures & Outcomes \\
\hline Haber MG et al [51] & $\begin{array}{l}\text { Transition-age youth and } \\
\text { young adults, aged } 14-21 \text {, } \\
\text { with serious mental health } \\
\text { conditions participating } \\
\text { in community-based } \\
\text { transition support } \\
\text { programs }\end{array}$ & $\begin{array}{l}\text { Longitudinal study } \\
\text { with one year's } \\
\text { follow-up of } 193 \\
\text { participants (most } \\
\text { other participants } \\
\text { lacked follow up) }\end{array}$ & $\begin{array}{l}\text { Employment, } \\
\text { education, criminal } \\
\text { involvement, effect } \\
\text { of mental health } \\
\text { on functioning, } \\
\text { substance use }\end{array}$ & $\begin{array}{l}\text { Improvement was most consistent for } \\
\text { education and employment. Criminal } \\
\text { justice involvement, mental health } \\
\text { interference and substance abuse } \\
\text { generally improved, but this was less } \\
\text { marked, or less consistent between } \\
\text { centres, in younger service users and } \\
\text { those with disruptive behaviour disorders }\end{array}$ \\
\hline Gilmer TP et al [54] & $\begin{array}{l}\text { Youths aged } 18-24 \\
\text { ( } n=931) \text { enrolled in } \\
\text { transition programmes and } \\
\text { youth controls }(n=1,574) \\
\text { enrolled in standard adult } \\
\text { outpatient programmes }\end{array}$ & $\begin{array}{l}\text { Comparison of } \\
\text { resource utilisation } \\
\text { (use of outpatient, } \\
\text { inpatient, emergency } \\
\text { and justice system } \\
\text { services) pre- and } \\
\text { post-enrolment } \\
\text { between } 2004 \text { and } \\
2009\end{array}$ & $\begin{array}{l}\text { Outpatient } \\
\text { visits, inpatient } \\
\text { admissions, } \\
\text { emergency } \\
\text { department } \\
\text { admissions, days } \\
\text { receiving mental } \\
\text { health services }\end{array}$ & $\begin{array}{l}\text { Compared with youths in adult } \\
\text { outpatient programmes, clients in } \\
\text { youth-specific outpatient programmes } \\
\text { had a greater post-enrolment increase } \\
\text { in outpatient visits ( } 21 \text { vs } 9 ; \text {; }<.001 \text { ). } \\
\text { There were no statistically significant } \\
\text { differences in inpatient admissions, use } \\
\text { of emergency services, or jail service } \\
\text { days. }\end{array}$ \\
\hline
\end{tabular}




\begin{tabular}{|c|c|c|c|c|}
\hline Styron et al, 2006 [98] & $\begin{array}{l}\text { Young adults, mean age } \\
20, \text { with a history of } \\
\text { psychosexual behaviour } \\
\text { problems, pervasive } \\
\text { developmental disorders } \\
\text { and a history of high- } \\
\text { risk behaviours, or other } \\
\text { behavioural needs }(n=60)\end{array}$ & $\begin{array}{l}\text { Structured interview, } \\
\text { clinician assessment }\end{array}$ & $\begin{array}{l}\text { Psychiatric } \\
\text { symptoms, youth } \\
\text { functioning, quality } \\
\text { of life, loneliness, } \\
\text { anger expression, } \\
\text { attachment, social } \\
\text { desirability }\end{array}$ & $\begin{array}{l}\text { Two aspects of treatment correlated } \\
\text { with outcomes: recipients of strengths- } \\
\text { focused treatment planning and } \\
\text { community-focused treatment planning } \\
\text { had fewer symptoms, less loneliness, } \\
\text { higher functioning, and greater service } \\
\text { satisfaction. } \\
\text { Longer participation was associated } \\
\text { with higher quality of life, greater service } \\
\text { satisfaction, higher functioning and less } \\
\text { loneliness. }\end{array}$ \\
\hline Cadario et al [45] & $\begin{array}{l}\text { Adolescents and young } \\
\text { adults with type } 1 \text { diabetes } \\
\text { discharged from paediatric } \\
\text { service }(n=62)\end{array}$ & $\begin{array}{l}\text { Retrospective } \\
\text { comparison of } \\
\text { group transferred } \\
\text { to adult service with } \\
\text { structured care plan } \\
\text { or in unstructured } \\
\text { way }\end{array}$ & $\begin{array}{l}\text { Date of first } \\
\text { admission in adult } \\
\text { service, HbA1c, } \\
\text { clinic attendance } \\
\text { rate in paediatric } \\
\text { vs. adult services, } \\
\text { phone } \\
\text { questionnaire } \\
\text { on transition } \\
\text { experience }\end{array}$ & $\begin{array}{l}\text { Structured group had fewer visits, } \\
\text { assessments for complications, GP help } \\
\text { and self-care without nursing help. } \\
\text { Most in both groups rated the service } \\
\text { good (no significant difference); more in } \\
\text { structured group rated transition good. }\end{array}$ \\
\hline $\begin{array}{l}\text { Johnston J et al } 2008 \\
\text { [56] }\end{array}$ & $\begin{array}{l}\text { Young people with diabe- } \\
\text { tes aged } 16 \otimes 25(n=-33)\end{array}$ & $\begin{array}{l}\text { Audit of new clinic } \\
\text { for young people }\end{array}$ & $\begin{array}{l}\text { Clinic attendance } \\
\text { and } \mathrm{HbAlc} \\
\text { for } 2 \text { years before } \\
\text { transfer and } 15-18 \\
\text { months after }\end{array}$ & $\begin{array}{l}\text { No difference in attendance pre- and } \\
\text { post-transition. } \\
\text { Fewer patients with poor glycaemic } \\
\text { control (HbA1c }>9 \%) \text { had good } \\
\text { attendance. } \\
\text { Before transfer, } \mathrm{HbA} 1 \mathrm{c} \text { was }<7.6 \% \text { in } 21 \% \text {, } \\
7.6-9.0 \% \text { in } 24 \% \text { and }>9.0 \% \text { in } 55 \% \text {. After } \\
\text { transfer, } \mathrm{HbA} 1 \mathrm{c} \text { was }<7.6 \% \text { in } 37 \%, 7.6- \\
9.0 \% \text { in } 37 \% \text { and }>9.0 \% \text { in } 26 \% \text {. }\end{array}$ \\
\hline Logan et al 2006 [57] & $\begin{array}{l}17 \text { - } 18 \text { year-olds with } \\
\text { diabetes }(n=93)\end{array}$ & $\begin{array}{l}\text { Audit of transition } \\
\text { clinic }\end{array}$ & $\begin{array}{l}\text { Satisfaction survey, } \\
\text { audit after } 3 \text { years }\end{array}$ & $\begin{array}{l}84 \% \text { attendance over } 3 \text { years. } \\
\text { Mean } \mathrm{HbA} 1 \mathrm{c} \text { at first visit } 9.7 \% \text { (range } \\
6.0-18 \% \text {; } n=93 \text { ), falling to } 9.0 \% \text { by third } \\
\text { visit. Patients with } \mathrm{HbA} 1 \mathrm{c}<7.5 \% \text { increased } \\
\text { from } 13 \% \text { to } 33 \% \text {. }\end{array}$ \\
\hline Holmes-Walker et al [44 ] & $\begin{array}{l}15-25 \text {-year-olds with } \\
\text { type } 1 \text { diabetes }(n=191)\end{array}$ & $\begin{array}{l}\text { Review of transition } \\
\text { clinic; comparison } \\
\text { with historical } \\
\text { controls. }\end{array}$ & $\begin{array}{l}\text { Admission } \\
\text { for diabetic } \\
\text { ketoacidosis, HbA1c }\end{array}$ & $\begin{array}{l}\text { Mean } \mathrm{HbA} 1 \mathrm{c} \text { at first attendance } 9.3 \% \text {; } \\
54 \% \text { patients with }<9.0 \% \text { and } 13 \%<7.0 \% \text {. } \\
\text { After at least } 2 \text { appointments (median } 5 \text { ), } \\
\text { mean } \mathrm{HbA} 1 \mathrm{c} \text { was significantly lower at } \\
8.8 \% \text {; with } 60 \% \text { at } 9.0 \% \text { and } 15 \% \text { at }<7.0 \% \text {. } \\
\text { Significant reduction in DKA admission } \\
\text { rates to about two-thirds of previous } \\
\text { rate, but no significant change in the } \\
\text { number of readmissions. } \\
\text { Length of stay after readmission } \\
\text { significantly lower, but total admission } \\
\text { length of stay unchanged. }\end{array}$ \\
\hline Vidal et al [58] & $\begin{array}{l}\text { Young adults (mean age 19) } \\
\text { with diabetes }(n=80)\end{array}$ & $\begin{array}{l}\text { Review of transition } \\
\text { clinic after one year }\end{array}$ & $\begin{array}{l}\text { HbA1c, } \\
\text { hypoglycaemic } \\
\text { events, change in } \\
\text { insulin dose, self- } \\
\text { management }\end{array}$ & $\begin{array}{l}\text { Metabolic control improved: mean } \\
\text { HbA1c } 8.5 \% \text { reduced to } 7.4 \%, p<0.001 \text {. } \\
\text { Fewer hypoglycaemic episodes: severe: } \\
0.39 \text { vs } 0.14 \text { episodes/patient/year, } \\
p<0.001 ;>5 \text { non-severe/weak: } 15 \% \text { vs } 0 \% \\
\text { patients, } p<0.005 \text {. } \\
\text { No change in total daily insulin dose, but } \\
\text { more patients using a rapid-acting insulin } \\
\text { ( } 23 \% \text { vs } 52 \% \text {, p }<0.001 \text { ). } \\
\text { More patients adjusting their own insulin } \\
\text { dose after } 12 \text { months ( } 48 \% \text { vs } 13 \% \\
\text { p }<0.001 \text { ). } \\
\text { Improved knowledge of diabetes; no } \\
\text { change in quality of life score. }\end{array}$ \\
\hline
\end{tabular}

